for conservation globally

Threatened

通
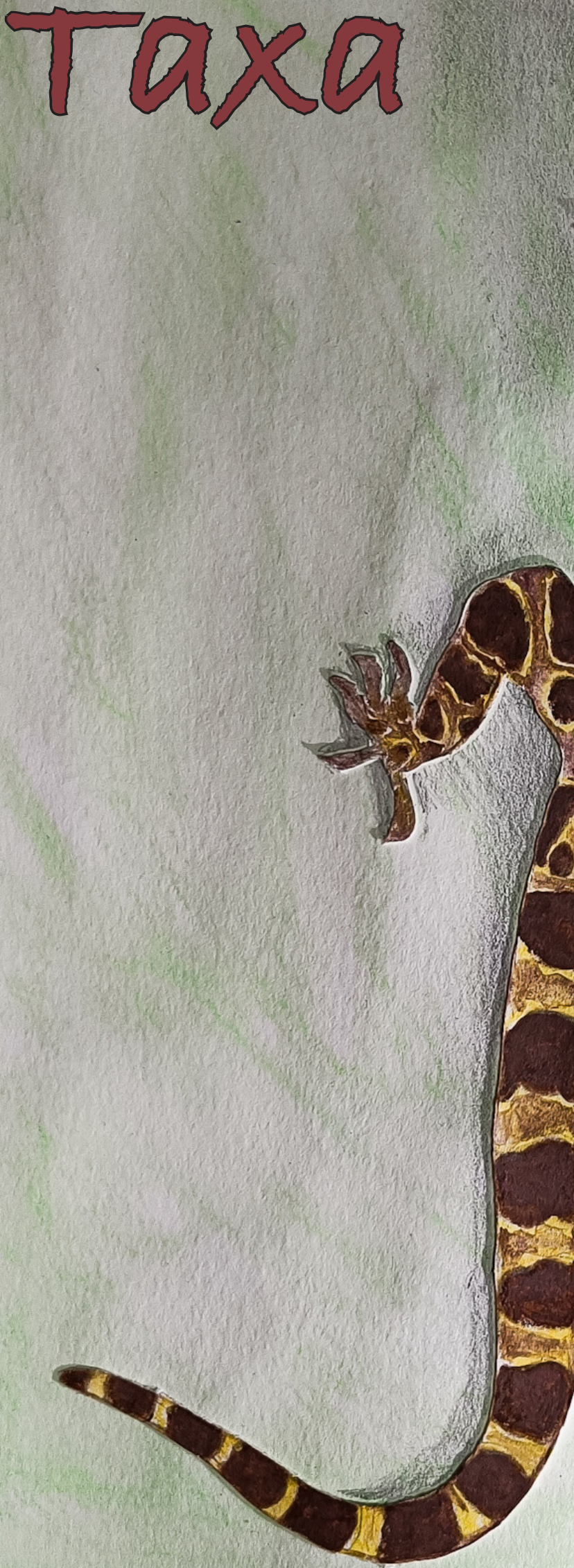

Open Access

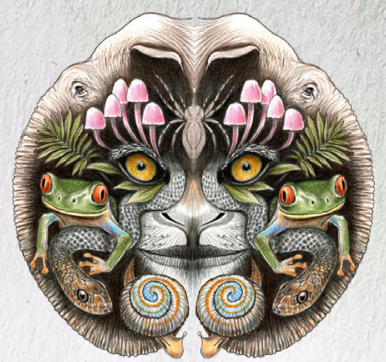

$10.1160 \mathrm{~g} / \mathrm{j}$ ott.2022.14.1.20311-20538 wWw.threatenedtaxa.org

26 January 2022 (Online \& Print) 14(1): 20311-20538 ISSN0974-7907 (Online) ISSN 0974-7893 (Print) 


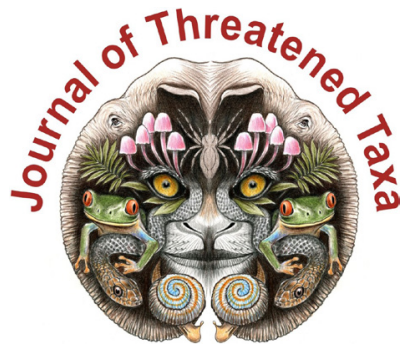

ISSN 0974-7907 (Online); ISSN $0974-7893$ (Print)

Publisher

Host

Wildlife Information Liaison Development Society

www.wild.zooreach.org

Zoo Outreach Organization www.zooreach.org

No. 12, Thiruvannamalai Nagar, Saravanampatti - Kalapatti Road, Saravanampatti, Coimbatore, Tamil Nadu 641035, India

Ph: +91 9385339863 | www.threatenedtaxa.org

Email: sanjay@threatenedtaxa.org

EDITORS

\section{Founder \& Chief Editor}

Dr. Sanjay Molur

Wildlife Information Liaison Development (WILD) Society \& Zoo Outreach Organization (ZOO),

12 Thiruvannamalai Nagar, Saravanampatti, Coimbatore, Tamil Nadu 641035, India

\section{Deputy Chief Editor}

Dr. Neelesh Dahanukar

Noida, Uttar Pradesh, India

\section{Managing Editor}

Mr. B. Ravichandran, WILD/ZOO, Coimbatore, India

\section{Associate Editors}

Dr. Mandar Paingankar, Government Science College Gadchiroli, Maharashtra 442605, India

Dr. Ulrike Streicher, Wildlife Veterinarian, Eugene, Oregon, USA

Ms. Priyanka Iyer, ZOO/WILD, Coimbatore, Tamil Nadu 641035, India

Dr. B.A. Daniel, ZOO/WILD, Coimbatore, Tamil Nadu 641035, India

\section{Editorial Board}

Dr. Russel Mittermeier

Executive Vice Chair, Conservation International, Arlington, Virginia 22202, USA

\section{Prof. Mewa Singh Ph.D., FASc, FNA, FNASc, FNAPsy}

Ramanna Fellow and Life-Long Distinguished Professor, Biopsychology Laboratory, and Institute of Excellence, University of Mysore, Mysuru, Karnataka 570006, India; Honorary Professor, Jawaharlal Nehru Centre for Advanced Scientific Research, Bangalore; and Adjunct Professor, National Institute of Advanced Studies, Bangalore

\section{Stephen D. Nash}

Scientific Illustrator, Conservation International, Dept. of Anatomical Sciences, Health Sciences Center, T-8, Room 045, Stony Brook University, Stony Brook, NY 11794-8081, USA

\section{Dr. Fred Pluthero}

Toronto, Canada

\section{Dr. Priya Davidar}

Sigur Nature Trust, Chadapatti, Mavinhalla PO, Nilgiris, Tamil Nadu 643223, India

\section{Dr. Martin Fisher}

Senior Associate Professor, Battcock Centre for Experimental Astrophysics, Cavendish

Laboratory, JJ Thomson Avenue, Cambridge CB3 OHE, UK

\section{Dr. John Fellowes}

Honorary Assistant Professor, The Kadoorie Institute, 8/F, T.T. Tsui Building, The University of Hong Kong, Pokfulam Road, Hong Kong

\section{Prof. Dr. Mirco Solé}

Universidade Estadual de Santa Cruz, Departamento de Ciências Biológicas, Vice-coordenado do Programa de Pós-Graduação em Zoologia, Rodovia Ilhéus/Itabuna, Km 16 (45662-000)

Salobrinho, Ilhéus - Bahia - Brasil

\section{Dr. Rajeev Raghavan}

Professor of Taxonomy, Kerala University of Fisheries \& Ocean Studies, Kochi, Kerala, India

\section{English Editors}

Mrs. Mira Bhojwani, Pune, India

Dr. Fred Pluthero, Toronto, Canad

Mr. P. Ilangovan, Chennai, India

Web Development

Mrs. Latha G. Ravikumar, ZOO/WILD, Coimbatore, India

\section{Typesetting}

Mr. Arul Jagadish, ZOO, Coimbatore, India

Mrs. Radhika, ZOO, Coimbatore, India

Mrs. Geetha, ZOO, Coimbatore India
Fundraising/Communications

Mrs. Payal B. Molur, Coimbatore, India

Subject Editors 2018-2020

Fungi

Dr. B. Shivaraju, Bengaluru, Karnataka, India

Dr. R.K. Verma, Tropical Forest Research Institute, Jabalpur, India

Dr. Vatsavaya S. Raju, Kakatiay University, Warangal, Andhra Pradesh, India

Dr. M. Krishnappa, Jnana Sahyadri, Kuvempu University, Shimoga, Karnataka, India

Dr. K.R. Sridhar, Mangalore University, Mangalagangotri, Mangalore, Karnataka, India

Dr. Gunjan Biswas, Vidyasagar University, Midnapore, West Bengal, India

\section{Plants}

Dr. G.P. Sinha, Botanical Survey of India, Allahabad, India

Dr. N.P. Balakrishnan, Ret. Joint Director, BSI, Coimbatore, India

Dr. Shonil Bhagwat, Open University and University of Oxford, UK

Prof. D.J. Bhat, Retd. Professor, Goa University, Goa, India

Dr. Ferdinando Boero, Università del Salento, Lecce, Italy

Dr. Dale R. Calder, Royal Ontaro Museum, Toronto, Ontario, Canada

Dr. Cleofas Cervancia, Univ. of Philippines Los Baños College Laguna, Philippines

Dr. F.B. Vincent Florens, University of Mauritius, Mauritius

Dr. Merlin Franco, Curtin University, Malaysia

Dr. V. Irudayaraj, St. Xavier's College, Palayamkottai, Tamil Nadu, India

Dr. B.S. Kholia, Botanical Survey of India, Gangtok, Sikkim, India

Dr. Pankaj Kumar, Kadoorie Farm and Botanic Garden Corporation, Hong Kong S.A.R., China

Dr. V. Sampath Kumar, Botanical Survey of India, Howrah, West Bengal, India

Dr. A.J. Solomon Raju, Andhra University, Visakhapatnam, India

Dr. Vijayasankar Raman, University of Mississippi, USA

Dr. B. Ravi Prasad Rao, Sri Krishnadevaraya University, Anantpur, India

Dr. K. Ravikumar, FRLHT, Bengaluru, Karnataka, India

Dr. Aparna Watve, Pune, Maharashtra, India

Dr. Qiang Liu, Xishuangbanna Tropical Botanical Garden, Yunnan, China

Dr. Noor Azhar Mohamed Shazili, Universiti Malaysia Terengganu, Kuala Terengganu, Malaysia

Dr. M.K. Vasudeva Rao, Shiv Ranjani Housing Society, Pune, Maharashtra, India

Prof. A.J. Solomon Raju, Andhra University, Visakhapatnam, India

Dr. Mandar Datar, Agharkar Research Institute, Pune, Maharashtra, India

Dr. M.K. Janarthanam, Goa University, Goa, India

Dr. K. Karthigeyan, Botanical Survey of India, India

Dr. Errol Vela, University of Montpellier, Montpellier, France

Dr. P. Lakshminarasimhan, Botanical Survey of India, Howrah, India

Dr. Larry R. Noblick, Montgomery Botanical Center, Miami, USA

Dr. K. Haridasan, Pallavur, Palakkad District, Kerala, India

Dr. Analinda Manila-Fajard, University of the Philippines Los Banos, Laguna, Philippines

Dr. P.A. Sinu, Central University of Kerala, Kasaragod, Kerala, India

Dr. Afroz Alam, Banasthali Vidyapith (accredited A grade by NAAC), Rajasthan, India

Dr. K.P. Rajesh, Zamorin's Guruvayurappan College, GA College PO, Kozhikode, Kerala, India

Dr. David E. Boufford, Harvard University Herbaria, Cambridge, MA 02138-2020, USA

Dr. Ritesh Kumar Choudhary, Agharkar Research Institute, Pune, Maharashtra, India

Dr. Navendu Page, Wildlife Institute of India, Chandrabani, Dehradun, Uttarakhand, India

\section{Invertebrates}

Dr. R.K. Avasthi, Rohtak University, Haryana, India

Dr. D.B. Bastawade, Maharashtra, India

Dr. Partha Pratim Bhattacharjee, Tripura University, Suryamaninagar, India

Dr. Kailash Chandra, Zoological Survey of India, Jabalpur, Madhya Pradesh, India

Dr. Ansie Dippenaar-Schoeman, University of Pretoria, Queenswood, South Africa

Dr. Rory Dow, National Museum of natural History Naturalis, The Netherlands

Dr. Brian Fisher, California Academy of Sciences, USA

Dr. Richard Gallon, llandudno, North Wales, LL30 1UP

Dr. Hemant V. Ghate, Modern College, Pune, India

Dr. M. Monwar Hossain, Jahangirnagar University, Dhaka, Bangladesh

Mr. Jatishwor Singh Irungbam, Biology Centre CAS, Branišovská, Czech Republic.

Dr. Ian J. Kitching, Natural History Museum, Cromwell Road, UK

Dr. George Mathew, Kerala Forest Research Institute, Peechi, India

For Focus, Scope, Aims, and Policies, visit https://threatenedtaxa.org/index.php/JoTT/aims_scope
For Article Submission Guidelines, visit https://threatenedtaxa.org/index.php/JoTT/about/submissions
For Policies against Scientific Misconduct, visit https://threatenedtaxa.org/index.php/JoTT/policies_various

continued on the back inside cover 


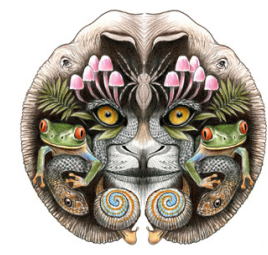

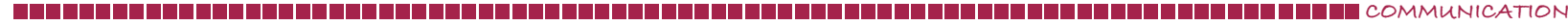

\title{
Raptors observed (1983-2016) in National Chambal Gharial Sanctuary: semi-arid biogeographic region suggestions for parametric studies on ecological continuity in Khathiar-Gir Ecoregion, India
}

\author{
L.A.K. Singh ${ }^{1}$ (D) R.K. Sharma ${ }^{2}$ (D) \& Udayan Rao Pawar ${ }^{3}$ (D) \\ ${ }^{1}$ Puspaswini, 1830 Mahatab Road, Old Town, Bhubaneswar, Odisha 751002, India. \\ ${ }^{2}$ National Chambal Sanctuary, Morena, Madhya Pradesh 476001, India. \\ ${ }^{3}$ Pawar Kothi, Dusshera Maidan, near G.R. Medical College, Gwalior, Madhya Pradesh 474009, India. \\ ${ }^{1}$ laksinghindia@gmail.com (corresponding author), ${ }^{2}$ rksharma_ncs@yahoo.com, ${ }^{3}$ udayanraopawar17@gmail.com
}

\begin{abstract}
The birds of prey or raptors in the National Chambal Sanctuary (NCS) assume importance as they are among the top predators of the region, predating on small crocodilians, turtles, and birds. Our checklist of 30 species of raptors is developed from observations made during winter surveys conducted between 1983 and 2016. The study area covered the course of river Chambal including its confluence with river Kuno that leads from Palpur-Kuno Sanctuary in Madhya Pradesh. The raptors which use the steep and inaccessible mud cliffs of the Chambal landscape include Bonelli's Eagle Aquila fasciata, Laggar Falcon Falco jugger, Egyptian Vulture Neophron percnopterus, White-rumped Vulture Gyps bengalensis, Spotted Owlet Athene brama, and the Indian Eagle-Owl or Rock Eagle Owl Bubo bengalensis. Most of the other raptors noted in NCS appear to visit from and around the adjoining wildlife areas of Rajasthan and Madhya Pradesh. According to two methods of classification the study comes in the semi-arid biogeographic zone or Khathiar-Gir dry deciduous forest ecoregion. The list of raptors from NCS-Kuno has been compared with previous reports and the list available for Sariska Tiger Reserve and Ranthambhore Tiger Reserve in Rajasthan. The present work is the outcome of a long-term ecological monitoring that primarily focused on the Gharial Gavialis gangeticus and its ecological associates in water and the riverine shores. The birds of prey demanded time and attention for looking above and away from the water surface or the shorelines. Yet, our meticulous records maintained over 34 years have generated a basal profile that is expected to inspire focused studies on parameters that sustain ecological association of raptors of NCS adjoining forest habitats and wildlife sanctuaries in the ecoregion.
\end{abstract}

Keywords: Chambal, crocodile predator, ecological continuity, Khathiar-Gir Ecoregion, National Chambal Sanctuary, Palpur-Kuno Sanctuary, Ranthambhore Tiger Reserve, Raptor checklist, Sariska Tiger Reserve, semi-arid biogeographic region.

Citation: Singh, L.A.K., R.K. Sharma \& U.R. Pawar (2022). Raptors observed (1983-2016) in National Chambal Gharial Sanctuary: semi-arid biogeographic region suggestions for parametric studies on ecological continuity in Khathiar-Gir Ecoregion, India. Journal of Threatened Taxa 14(1): 20444-20460. https://doi. org/10.11609/jott.7437.14.1.20444-20460

Copyright: (C) Singh et al. 2022. Creative Commons Attribution 4.0 International License. JoTT allows unrestricted use, reproduction, and distribution of this article in any medium by providing adequate credit to the author(s) and the source of publication.

Funding: None.

Competing interests: The authors declare no competing interests.

Hindi abstract: See end of this article.

Author details: L.A.K. SINGH-Former Asst. Director / Officer-in-Charge, erstwhile Central Crocodile Breeding and Management Training Institute, Hyderabad, Government of India; started the Field Camp of Crocodile Research Centre, Wildlife Institute of India at Deori, National Chambal Sanctuary in 1983. Superannuated from service Senior Research Officer (Wildlife) with Forest and Environment Department- Odisha in December 2010. R.K. SHARMA-Former Research Range Officer, National Chambal Sanctuary (NCS); with LAKS authored the first reports on bird and dolphin in NCS; superannuated from service in Madhya Pradesh Forest Department in September 2016. UR. PAWAR - a freelance photographer from Gwalior; won the Wildlife Photographer of the Year award 2013 by the Natural History Museum and BBC Worldwide.

Author contributions: RKS contributed the primary checklist and the photographs with URP. LAKS developed the analytical text with illustrations.

Acknowledgements: LAKS and RKS are thankful to the forest departments of Madhya Pradesh, Rajasthan, and Uttar Pradesh, particularly to the officers and staff of the National Chambal Sanctuary where they received full support and cooperation for over 34 years. Many local people have interacted with them during the observations and have provided local shelters where needed on the banks of the Chambal. URP is grateful for his participation in the survey. 


\section{INTRODUCTION}

\section{Background to the study}

The UNDP/FAO/Government of India Project for Conservation of Crocodiles which was initiated in 197475 (Bustard 1999) concluded in 1982 (de Vos 1984) with several significant contributions to a scenario in Indian wildlife conservation (Singh 1999). The next year, at the behest of the Government of India, LAKS from the erstwhile Central Crocodile Breeding and Management Training Institute (CCBMTI), Hyderabad, established and pursued teamed-up research goals in National Chambal Sanctuary (NCS), with headquarters at Deori Village Gharial Rearing Centre in Morena district, Madhya Pradesh. Since then, annual monitoring of Gharials and incidental collection of ecological and biological data of prominent wetland fauna has been carried out with simple protocols, for highlighting the results of wildlife management in NCS.

Much of the research work from NCS in this context is focused on Gharial, Mugger crocodile, Gangetic Dolphins, turtles, and non-raptor birds (Singh \& Rao 1984, 1985; Singh 1985; Singh \& Sharma 1985, 2015, 2018; Rao \& Singh 1987a,b,c; Sharma \& Singh 1986, 2014, 2015, 2018; Sharma et al. 1995). Until superannuation in 2016, fieldwork continued with RKS, a key member of the NCS team. The records on the birds of prey during the river surveys were occasional as they demanded attention for looking above and away from the water surface or the shorelines. However, because of meticulous records maintained over a long time, attention was reverted to raptors which are among the biological predators of crocodiles and large birds.

The raptors or birds of prey, while predating upon fish and bird fledglings, also predate through creche of crocodilian hatchlings and small juveniles of Gharial and Mugger. Although cursory remarks on predation aspects have been made in our previous publications, a separate treatment for raptors was not attempted. Sharma \& Singh (1986) who covered field studies during 1983-1985, observed 10 species of raptors, namely, Western Osprey Pandion haliaetus, Black Kite Milvus migrans, Black-shouldered Kite Elanus axillaris, Egyptian Vulture Neophron percnopterus, White-rumped Vulture Gyps bengalensis, Red-headed Vulture Sarcogyps calvus, Pallas's Fish Eagle Haliaeetus leucoryphus, Tawny Eagle Aquila rapax, Western Barn Owl Tyto alba, and Spotted Owlet Athene brama.

\section{Raptors among crocodile predators}

Elsewhere, Vyas (2019) provided a list of predators which affect nests or young ones of different crocodilian species. In this list, the species of birds that are known to predate on crocodilians are the Crow, Black or Pariah Kite, egrets, Purple Heron, Black-necked Stork, Painted Stork, Sarus Crane, and the White-bellied Sea Eagle. The presence of all species except the White-bellied Sea Eagle, is recorded for NCS (Sharma \& Singh 1986). Gopi \& Pandav (2006) and Palei et al. (2019) have reported or photographed the White-bellied Sea Eagle Haliaeetus leucogaster preying on Saltwater Crocodile Crocodylus porosus. The role of raptors in decimating populations of Mugger Crocodile Crocodylus palustris by 1975 (Singh 1979) in Similipal Tiger Reserve, Odisha cannot be ruled out, but Singh (1993) gave a list of 25 raptors seen here.

The raptors are among the world's most graceful and spectacular birds for their characteristic display of wings in flight, their body colour, and the size and shape of the tail. The high visual acuity of eagles in bright daylight and the highly sensitive vision of owls with adaptations to dim-light vision has fascinated mankind (Potier et al. 2020). Being predators at the top, the birds of prey live in low numbers. The threats to tropical raptors include habitat destruction, environmental contamination, and persecution or shooting (Bildstein et al. 1998; Prakash et al. 2003; Green et al. 2004; Meteyer et al. 2004; Shultz et al. 2004; Swan et al. 2006a,b; Hernández \& Margalida 2009; Zabala et al. 2020).

Out of 292 species of tropical raptors, 76\% (222) are completely in the tropics; and most of the forest dwelling tropical raptors are secretive and difficult to study (Bildstein et al. 1998). The Chambal region supports a significant number of raptors and this is evident from numerous casual sightings and anecdotal references, as well as incidental observations. Based on our notes from the riverine landscape, and the taxonomic status given in the IOC World Bird List (Gill et al. 2021), the diurnal birds of prey that include hawks, eagles, and vultures are in the order Accipitriformes, and falcons in the order Falconiformes. Owls, which are nocturnal birds of prey are in order Strigiformes. A few of these species breed in the Chambal landscape. The steep and inaccessible mud cliffs appear to be preferred sites of Bonelli's Eagle, Laggar Falcon, Egyptian Vulture, White-rumped Vulture, Spotted Owlet, and Indian Eagle Owl.

In this note, we present a list of raptors that were incidentally sighted during our annual river surveys in the National Chambal Sanctuary and the Kuno confluence leading to Palpur-Kuno Sanctuary in Madhya Pradesh. Since the presence of some raptors does not get the support of breeding evidence along the Chambal, the raptor lists from Ranthambhore and Sariska have 
been compared for possible insight into their presence resulting from local flights and extended home range. We expect our study may stimulate more conclusive knowledge on these aspects from systematic raptorspecific studies in the future in the Chambal landscape within the semi-arid biogeographic zone (Rodgers \& Panwar 1988) and the Khathiar-Gir dry deciduous forest ecoregion (WWF 2021).

\section{STUDY AREA}

Chambal in northwest India is a clear and fast-flowing river that originates from the Vindhya Range in central India. A stretch of about $572 \mathrm{~km}$ of the river Chambal, bordering the states of Madhya Pradesh, Rajasthan, and Uttar Pradesh, constitutes the National Chambal Sanctuary (NCS) (Figure 1). The NCS is protected for conservation and management of the endangered Gharial Gavialis gangeticus since 1979.
The biodiversity components of the river under NCS holds a number of indicator fauna which include the crocodilians, chelonians, and avian species. Besides, there are the Gangetic Dolphins and otters. Within the sanctuary limits, the river banks have ravines with sparse ground cover. The natural vegetation comprises of thorn forests, forming most of the boundary for Madhya Pradesh. The nearest forested habitat is in the Kuno-Palpur Wildlife Sanctuary in Madhya Pradesh (Figure 2). However, close to NCS, there are a few forestbased well-known wildlife sanctuaries (WS) in Rajasthan. These include the Jawahar Sagar Wildlife Sanctuary and Ranthambhore Tiger Reserve in Rajasthan.

The habitat from Pali to Chakarnagar in Chambal (Figure 2) comprises the most significant area for the conservation of Gharial. Keeping in mind the conservation significance of the critically endangered gharial and its habitat, the population trends and

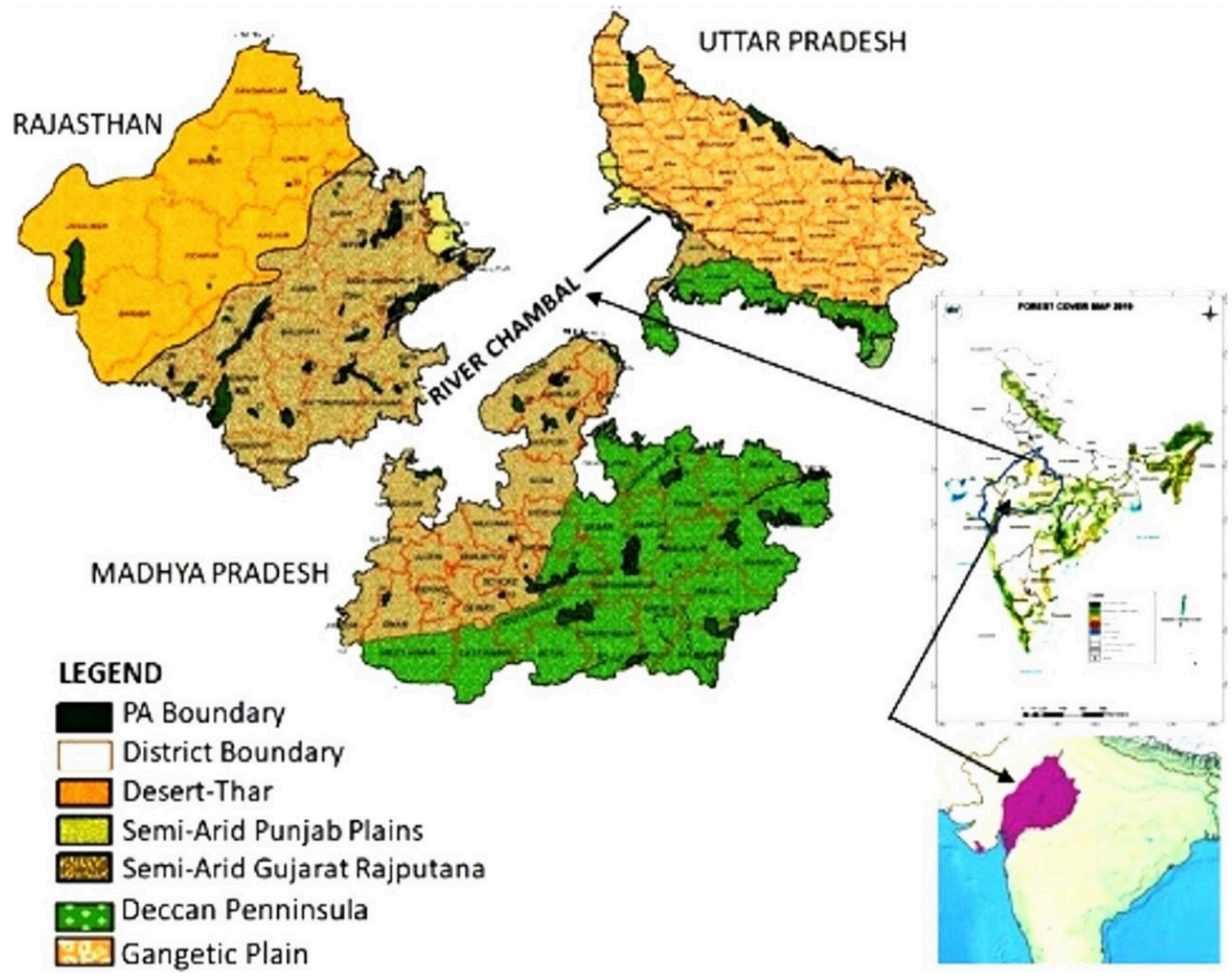

Figure 1. Locations of Wildlife Sanctuaries (PA, protected area boundary) with respect to River Chambal, National Chambal Sanctuary bordering the states of Rajasthan, Madhya Pradesh, and Uttar Pradesh within Khathiar-Gir dry deciduous forest ecoregion (inset, right bottom) in northwestern India. Source maps from ENVIS 2020, FSI 2019, Wikipedia 2021. 


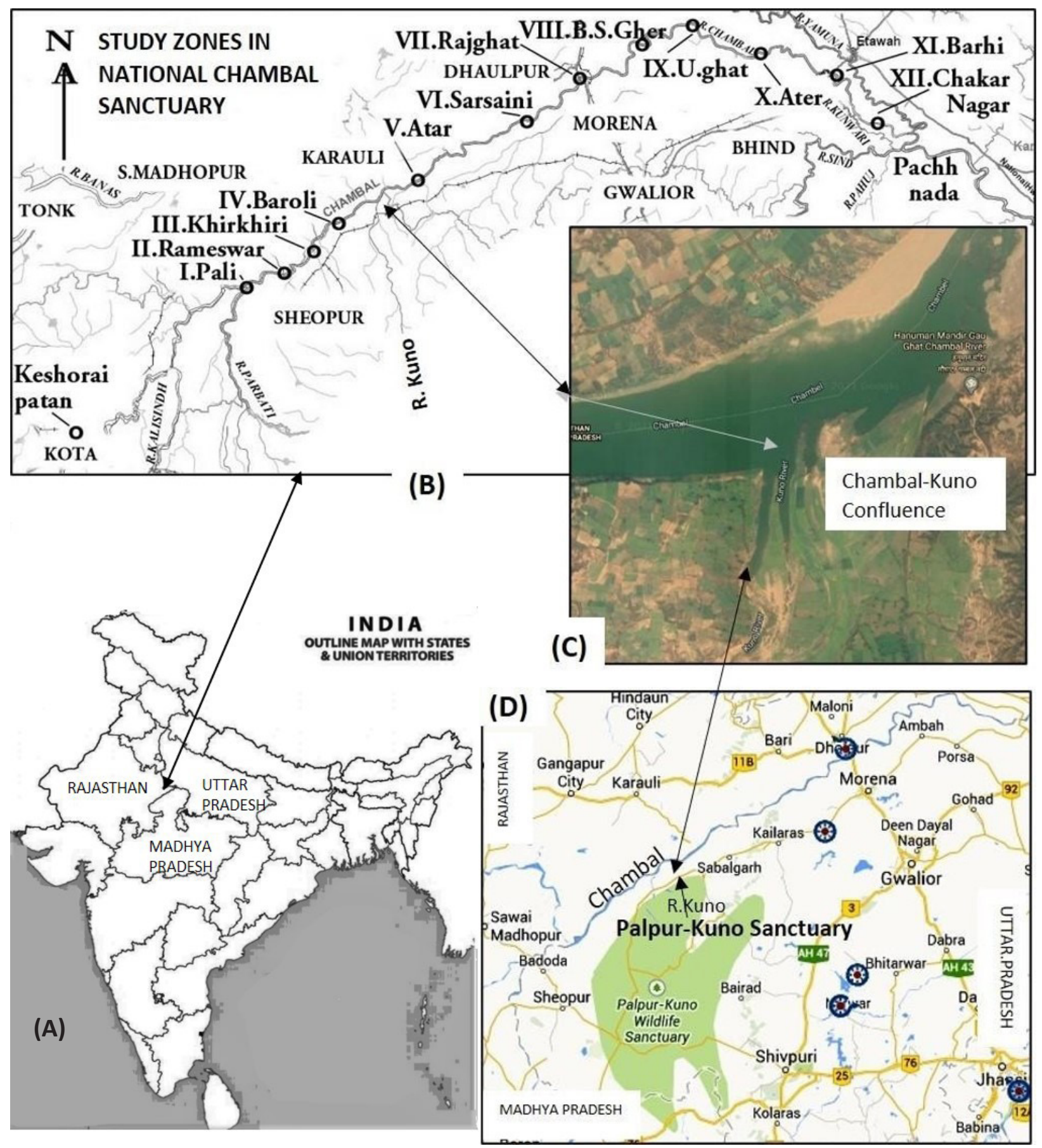

Figure 2. Map of India (A) showing study zones in National Chambal Sanctuary (B), the confluence with river Kuno (C) that originates from Palpur-Kuno Sanctuary (D).

probable threats are among the parameters that have been assessed regularly with defined gaps. Every year, Madhya Pradesh Forest Department takes a systematic initiative to carry out a comprehensive survey to find out the status and distribution of Gharial and its ecological associates in NCS. Sometimes, survey cruises by boat and foot are also extended into the tributaries like,
Parbati, Kali Sindh, Banas, and Kuno.

The Kuno-Chambal confluence is downstream of Nadigaon village which is a nesting site of Gharial and Mugger (Singh 1985; Sharma \& Singh 2015). Upstream of Nadigaon, the Baroli sandbank, and Baroli island are considered among the best nesting sites of gharial and offer scope to observe all the sequences of breeding 
behaviour by adults and creche formation by hatchlings. The hatchlings congregate around the confluence of the Kuno river, because of the availability of smaller fishes, and for retreat into the tributary during the flood. About $30 \mathrm{~km}$ upstream of the Kuno-confluence, the PalpurKuno WS was established in 1981 in the state of Madhya Pradesh with an initial area of about $344.68 \mathrm{~km}^{2}$. It is a dry deciduous forest forming a part of the Vindhyan hill range.

\section{MATERIALS AND METHODS}

The NCS was marked into twelve stretches of smaller study zones (Figure 2 based on Singh 1985) and the area was surveyed by travelling on a motor boat as well as by walking on foot. The surveyors were equipped with 1:50,000 toposheets from Survey of India, A4-size bits of field map sheets, binoculars, and a camera. The team along with the support staff normally moved between $0900 \mathrm{~h}$ and $1700 \mathrm{~h}$. during the winter. When moving by motorboat, the transect speeds ranged within $15 \mathrm{~km}$ per hour, depending on the demands of the situation and navigability of the stream. Birds were sighted with the help of binoculars (Olympus $10 \times 50 \mathrm{~mm}$ ), occasionally aided with a spotting scope. Field notes were made directly on the field map sheets or notebooks. The bird species were identified using standard field guides, such as Ali (1979, 2002), Naoroji (2011), and Grimmett et al. (2011). Observed species of raptors were recorded along with sighting time and nearest village name and other ancillary information on datasheets. A list of all the raptor species observed in the Chambal and Kuno region is given in Table 1. The recent names and synonyms are according to the International Ornithological CongressIOC World Bird List (Gill et al. 2021).

\section{RESULTS AND DISCUSSION}

\section{The Checklist of raptor birds in NCS-Kuno}

a) The list of raptors based on our observations comprises a total of 30 species (Table 1 and Supplement Table A). It includes six species of vultures, one osprey, two kites, one shikra, one harrier, three buzzards, five eagles, one kestrel, one hobby, two falcons, and seven owlet/owls. The family-wise list incorporates Falconidae four species, Accipitridae 18 species, Tytonidae one species, Strigidae six species, and Pandionidae one species.

b) In our list, a total of nine species falls under the
IUCN threatened categories of Critically Endangered (CR) (3), Endangered (EN) (2), Vulnerable (VU) (1), and Near Threatened (NT) (3) of which six are residents and three are winter visitors. Other 21 species, which includes six winter-visiting species, are with status of Least Concern (LC) (Table 1 and Supplement Table B).

c) Nine of the 30 species listed are winter visitors. These are Cinereous Vulture, Griffon Vulture, Western Osprey (seen through early summer till May), Western Marsh Harrier, Common Buzzard, Pallas's Fish Eagle, Tawny Eagle, Common Kestrel, and Eurasian Hobby (Table 1 and Supplement Table B). A detailed study on their migration pattern to the wetlands of river Chambal may indicate if NCS deserves to be considered as a Ramsar site.

d) Our preliminary observations indicate that the raptors received protection that is available as incidental to Gharial conservation in NCS.

e) In Wildlife (Protection) Act, India the Schedule-IV status is given to Cinereous Vulture, Egyptian Vulture and Red-headed Vulture. This, however, does not match the grave status given to these species under the IUCN as NT, EN, and CR, respectively (Table B). We agree that the Egyptian Vulture or Pharaoh's Chicken appear to be in relatively good numbers but because of their size they might be more prone to killing. The suggestions made here on the possible lift or upgradation of Scheduled status of these three raptors merits the attention of the Ministry of Environment, Forests and Climate Change (MOEFCC) and requires further consultation with established ornithologists of India.

\section{Species-wise total sightings}

a) The total number of birds counted during the survey period 2003-2016 was 2070, with a range of 85188 , and an average of 148 birds per year (Table 2). The moving average of the number of birds per year appears to indicate that NCS continues to be a good habitat for raptor sighting (Figure 3).

b) In the entire list (Table 1) there are seven species whose total count in 14 annual surveys has been less than five. These are, one bird per one survey for Cinereous Vulture (4 sightings), Griffon Vulture (4 sightings), Common Buzzard (4 sightings), White-eyed Buzzard (2 sightings), Crested Honey Buzzard (4 sightings), Pallas's Fish Eagle (1 sighting), and Dusky Eagle Owl (4 sightings).

c) Pallas Fish Eagle was last seen in 1986 (Supplement Table A) and has not been recorded since then. There has been an increase in the number of sightings of Western Osprey over the years. Although the Western Osprey is considered to be a winter visitor, it is seen in Chambal in 
Table 1. Species of raptors observed in National Chambal Sanctuary over 14 surveys during 2003-2016 of Gharial monitoring. Where synonyms exist, the first mentioned name is according to the nomenclature in IOC World Bird List (v11.1) (Gill et al. 2021). Key to IUCN status: CRCritically Endangered | EN-Endangered | VU-Vulnerable | NT-Near Threatened | LC-Least Concern. 'Winter' in migratory status refers to months November to February.

\begin{tabular}{|c|c|c|c|c|c|c|c|}
\hline & English name & $\begin{array}{l}\text { Scientific } \\
\text { name }\end{array}$ & Location & $\begin{array}{c}\text { Total } \\
\text { raptor } \\
\text { counts } \\
\text { (max } 14 \\
\text { surveys }\end{array}$ & $\begin{array}{l}\text { Total } \\
\text { years } \\
\text { when } \\
\text { seen } \\
(\max 14)\end{array}$ & $\begin{array}{l}\text { IUCN } \\
\text { Red List } \\
\text { status }\end{array}$ & $\begin{array}{l}\text { Migratory } \\
\text { status }\end{array}$ \\
\hline 1 & Cinereous Vulture & Aegypius monachus & Chambal, Kuno & 4 & 3 & NT & Winter visitor \\
\hline 2 & Egyptian Vulture & Neophron percnopterus & Chambal, Kuno & 999 & 14 & EN & Resident \\
\hline 3 & $\begin{array}{l}\text { White-rumped Vulture (Indian } \\
\text { White-backed Vulture) }\end{array}$ & Gyps bengalensis & Kuno, Chambal & 80 & 14 & CR & Resident \\
\hline 4 & $\begin{array}{l}\text { Indian Vulture (Longbilled } \\
\text { Vulture) }\end{array}$ & Gyps indicus & Chambal, Kuno & 12 & 6 & CR & Resident \\
\hline 5 & Red-headed Vulture & Sarcogyps calvus & Chambal, Kuno & 30 & 13 & CR & Resident \\
\hline 6 & Griffon Vulture (Eurasian Griffon) & Gyps fulvus & Kuno & 4 & 4 & LC & Winter visitor \\
\hline 7 & Western Osprey (Osprey) & Pandion haliaetus & Chambal & 562 & 14 & LC & $\begin{array}{l}\text { Winter visitor, } \\
\text { seen till May }\end{array}$ \\
\hline 8 & Black-shouldered Kite & Elanus axillaris & Chambal, Kuno & 39 & 9 & LC & Resident \\
\hline 9 & Black Kite (Common Pariah Kite) & Milvus migrans & Chambal, Kuno & 62 & 8 & LC & Resident \\
\hline 10 & Shikra & Accipiter badius & Chambal & 74 & 14 & LC & Resident \\
\hline 11 & $\begin{array}{l}\text { Western Marsh Harrier (Eurasian } \\
\text { Marsh Harrier) }\end{array}$ & Circus aeruginosus & Chambal & 38 & 13 & LC & Winter visitor \\
\hline 12 & Common Buzzard & Buteo buteo & Chambal & 4 & 3 & LC & Winter visitor \\
\hline 13 & White-eyed Buzzard & Butastur teesa & Chambal, Kuno & 2 & 2 & LC & Resident \\
\hline 14 & $\begin{array}{l}\text { Crested Honey Buzzard (Oriental } \\
\text { Honey Buzzard) }\end{array}$ & Pernis ptilorhynchus & Chambal, Kuno & 4 & 4 & LC & Resident \\
\hline 15 & Bonelli's Eagle & Aquila fasciata & Chambal, Kuno & 29 & 10 & LC & Resident \\
\hline 16 & Pallas's Fish Eagle & Haliaeetus leucoryphus & Chambal & 0 & 0 & EN & Winter visitor \\
\hline 17 & Tawny Eagle & Aquila rapax & Chambal & 11 & 5 & VU & Winter visitor \\
\hline 18 & Crested Serpent Eagle & Spilornis cheela & Chambal & 5 & 4 & LC & Resident \\
\hline 19 & Changeable Hawk Eagle & $\begin{array}{l}\text { Nisaetus cirrhatus } \\
\text { (Spizaetus cirrhatus) }\end{array}$ & Kuno & 5 & 4 & LC & Resident \\
\hline 20 & Common Kestrel & Falco tinnunculus & Chambal & 29 & 10 & LC & Winter visitor \\
\hline 21 & Eurasian Hobby & Falco subbuteo & Kuno & 6 & 6 & LC & Winter visitor \\
\hline 22 & Laggar Falcon & Falco jugger & Chambal & 27 & 13 & NT & Resident \\
\hline 23 & Red-necked Falcon & Falco chicquera & Chambal & 9 & 7 & NT & Resident \\
\hline 24 & Spotted Owlet & Athene brama & Chambal & 4 & 4 & LC & Resident \\
\hline 25 & Western Barn Owl (Barn Owl) & Tyto alba & Chambal, Kuno & 5 & 4 & LC & Resident \\
\hline 26 & Dusky Eagle Owl & Bubo coromandus & Chambal & 4 & 4 & LC & Resident \\
\hline 27 & Brown Fish Owl & Ketupa zeylonensis & Kuno & 5 & 4 & LC & Resident \\
\hline 28 & Indian Scops Owl & Otus bakkamoena & Kuno & 7 & 5 & LC & Resident \\
\hline 29 & Mottled Wood Owl & Strix ocellata & Kuno & 5 & 4 & LC & Resident \\
\hline 30 & $\begin{array}{l}\text { Indian Eagle-Owl } \\
\text { (Rock Eagle Owl) }\end{array}$ & Bubo bengalensis & Kuno & 5 & 4 & LC & Resident \\
\hline
\end{tabular}




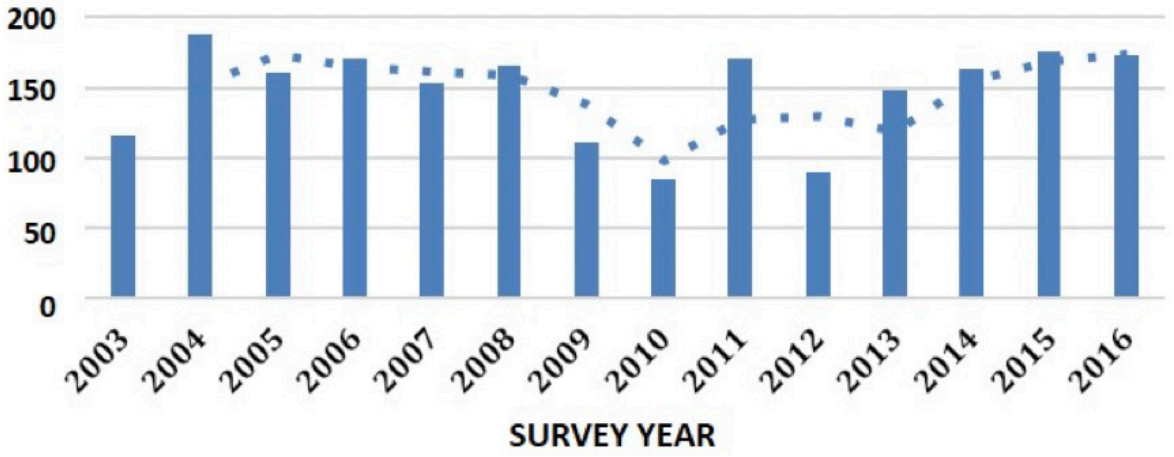

Figure 3. Number of raptor birds counted in different survey years 2003-2016, with moving average of the counts (dotted line) in National Chambal Sanctuary.

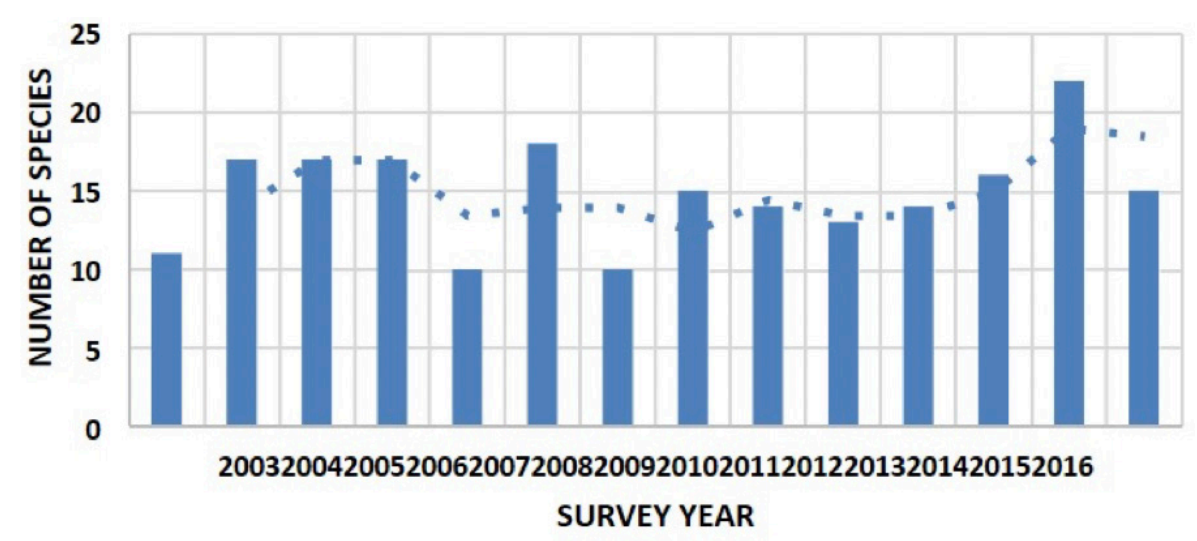

Figure 4. Number of raptor species noted in different survey years 20032016 with moving average (dotted line) in National Chambal Sanctuary. fair numbers until late summer.

d) Indian White-rumped Vultures were found in fair numbers in Chambal Sanctuary and large flocks could be seen until 1990, when a maximum of 304 vultures were recorded (Supplement Table A). Following this, there has been a steady decline. Only a total of four vultures were recorded in 2016

\section{Survey-year-wise species sightings (Table 2)}

a) Ten species of raptors appear to have NCS in their preferred home range. Seven species were observed for 11 or more of the total 14 continuous annual surveys. These are the Egyptian Vulture (14 years), Whiterumped Vulture (all 14 years), Red-headed Vulture (13 years), Western Osprey (all 14 years), Shikra (14 years), Western Marsh Harrier (13 years), and Laggar Falcon (13 years). There were two species that were seen in 10 out of 14 surveys. These species are the Bonelli's Eagle and Common Kestrel (Table 1).

b) During our survey years, 2003 to 2016, the number of species observed per year varied between 10 and 22 species (Table 2, Figure 4). In 1990, only three species of raptors were noted namely, the White-rumped Vulture with 304 counts, Indian Vulture four birds counted and
28 bird counts of Western Osprey (Supplement Table A).

c) Very low sightings or no sighting of a species during any survey indicates the basic territorial characteristics of raptors, the possibility of their long home range, their seasonal and migratory habits, and our winter-season linear survey along the $572 \mathrm{~km}$ long Chambal River. Moreover, the survey objectives were targeted at the species seen in the water or on the river banks.

d) The index describing year-wise raptor counts and raptor species is an average of 9.9. This demonstrates a fairly favourable relationship between the habitat of NCS and the appearance of raptors within its landscape. In the beginning, i.e., in 2003 it was 10.5 and in 2016 it was 11.5 with fluctuations between values 5.7 and 15.3 (Table 2; Figure 5).

e) It is expected that the index values may enable to construe conclusion on conservation impacts from NCS with details of ecological parameters influencing the survival and behaviour of raptors through decades since the 1980s.

\section{NCS-Kuno raptor names by other authors}

a) Lists of NCS raptors that were possible to access for comparison are in Mitra (1979), the management 


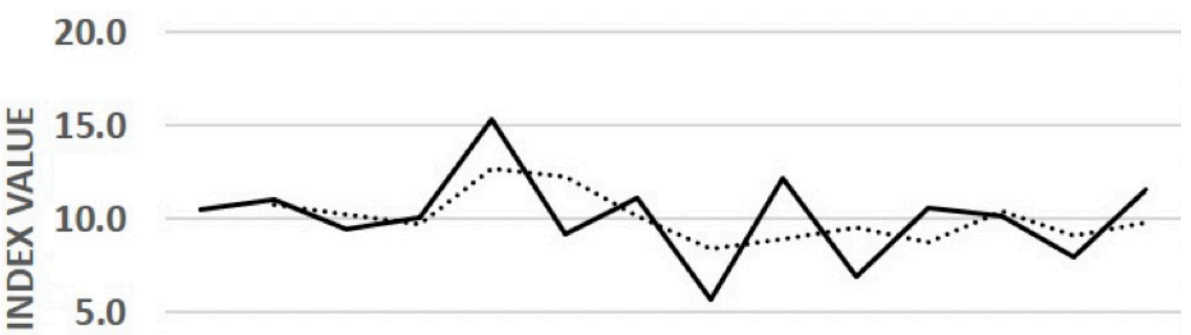

0.0

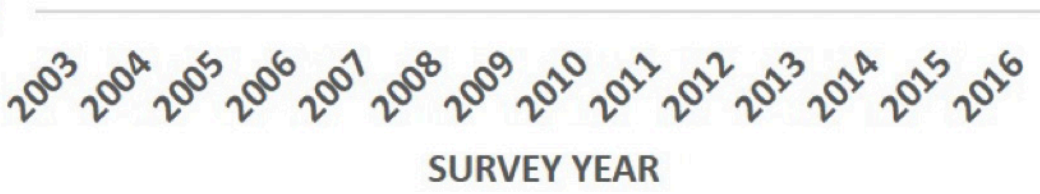

Figure 5. Trend in index value of 'Number of raptor species' and 'Number of raptor birds counted' in different survey years 2003-2016 with moving average (dotted line) in National Chambal Sanctuary.

Table 2. Year-wise survey with record of total numbers of species, raptor birds, and the trend of their index ratio.

\begin{tabular}{|c|c|c|c|}
\hline Year & Species no. & Raptor count & $\begin{array}{c}\text { Bird count / } \\
\text { Species count } \\
\text { index }\end{array}$ \\
\hline 2003 & 11 & 116 & 10.5 \\
\hline 2004 & 17 & 188 & 11.1 \\
\hline 2005 & 17 & 160 & 9.4 \\
\hline 2006 & 17 & 171 & 10.1 \\
\hline 2007 & 10 & 153 & 15.3 \\
\hline 2008 & 18 & 166 & 9.2 \\
\hline 2009 & 10 & 111 & 11.1 \\
\hline 2010 & 15 & 85 & 5.7 \\
\hline 2011 & 14 & 170 & 12.1 \\
\hline 2012 & 13 & 90 & 6.9 \\
\hline 2013 & 14 & 148 & 10.6 \\
\hline 2014 & 16 & 163 & 10.2 \\
\hline 2015 & 22 & 176 & 8.0 \\
\hline 2016 & 15 & 173 & 11.5 \\
\hline Total & 209 & 2070 & - \\
\hline Average & 14.9 & 147.9 & 9.9 \\
\hline
\end{tabular}

plan by Sale (1982), a Technical Report by Sharma \& Singh 1986, the management plan by Murthy (2004), the consolidated list in Nair \& Krishna (2013) and the proposed tri-state management plan by Choudhury et al. 2014. The list by Mitra (1979) was an original survey before our work commenced.

b) Mitra (1979) reported the presence of six raptor species. These were the Laggar Falcon, Pale Harrier, White-eyed Buzzard, Short-toed Eagle, Common Kestrel, and Crested Hawk Eagle (Changeable Hawk Eagle). Out of these, our observations till 2016 confirm the continued sighting of four species. These are the Laggar Falcon,
Kestrel, White-eyed Buzzard, and the Changeable Hawk Eagle.

c) In the consolidated list of the vertebrate fauna of the Chambal basin, Nair \& Krishna (2013) furnished a list of 308 bird species under 64 families. This list includes 45 species of raptors. These belong to Falconidae six species, Accipitridae 29 species, Tytonidae one species, and Strigidae nine species.

d) Given the gharial-oriented primary objectives, the season, and nature of our annual river surveys, we agree that our observations will not tally with other lists available for comparison.

\section{NCS-Kuno raptor list compared with Ranthambhore and Sariska (Table 3)}

a) Bildstein et al. (1998) mentioned 63 diurnal raptor species in India. Naoroji (2011) mentioned the occurrence of a total of 44 raptor species in the semiarid biogeographic zone, of which 26 are migrants and 18 are residents.

b) Since Chambal banks offer only the cliffs for limited perch or nest, we have attempted to compare our observed list with sanctuaries of Rajasthan that may be within the active home range of the raptors.

c) Eleven raptor species observed in NCS are also reported from Ranthambhore Tiger Reserve (RTR) (Anonymous 2021) and Sariska Tiger Reserve (STR) (Sultana 2013). These are the Black-shouldered Kite, Western Barn Owl, Common Kestrel, Crested Serpent Eagle, Indian Vulture, Crested Honey Buzzard, Redheaded Vulture, Shikra, Spotted Owlet, Brown Fish Owl, and Indian Scops Owl.

d) Six species are not reported either from RTR or STR. These are the Cinereous Vulture, Common Buzzard, Pallas's Fish Eagle, Changeable Hawk Eagle, Eurasian Hobby, and Indian Eagle Owl. Future studies will confirm 
Table-3. Comparison of raptors observed in National Chambal Sanctuary with reports from Ranthambhore Tiger Reserve (RTR) and Sariska Tiger Reserve (STR). Tharmalingam et al 2011 refers to report from Kuno-Palpur Sanctuary. P-Presence mentioned | N-Not mentioned. Ten of these species at serial numbers $2,3,5,7,8,9,16,17,24$ and 25 were observed in $1983-85$ and reported earlier in Sharma \& Singh 1986 (Supplement Table A).

\begin{tabular}{|c|c|c|c|c|c|}
\hline & Common name & Scientific name & $\begin{array}{c}\text { Anonymous } 2021 \\
\text { (RTR) }\end{array}$ & $\begin{array}{l}\text { Sultana } 2013 \\
\text { (STR) }\end{array}$ & $\begin{array}{c}\text { Kuno - Palpur } \\
\text { (Thermalingam et al 2011) }\end{array}$ \\
\hline 1 & Cinereous Vulture & Aegypius monachus & $\mathrm{N}$ & $\mathrm{N}$ & $\mathrm{N}$ \\
\hline 2 & Egyptian Vulture & Neophron percnopterus & $N$ & $P$ & $P$ \\
\hline 3 & White-rumped Vulture & Gyps bengalensis & N & $P$ & $P$ \\
\hline 4 & Indian Vulture & Gyps indicus & $P$ & $P$ & $P$ \\
\hline 5 & Red-headed Vulture & Sarcogyps calvus & $P$ & $P$ & $P$ \\
\hline 6 & Griffon Vulture & Gyps fulvus & $\mathrm{N}$ & $P$ & $\mathrm{~N}$ \\
\hline 7 & Western Osprey & Pandion haliaetus & N & $P$ & $P$ \\
\hline 8 & Black-shouldered Kite & Elanus axillaris & $P$ & $P$ & $\mathrm{~N}$ \\
\hline 9 & Black Kite & Milvus migrans & $P$ & $\mathrm{~N}$ & $\mathrm{~N}$ \\
\hline 10 & Shikra & Accipiter badius & $P$ & $P$ & $P$ \\
\hline 11 & Western Marsh Harrier & Circus aeruginosus & N & $P$ & $\mathrm{P}$ \\
\hline 12 & Common Buzzard & Buteo buteo & N & N & $\mathrm{N}$ \\
\hline 13 & White-eyed Buzzard & Butastur teesa & N & $P$ & $P$ \\
\hline 14 & Crested Honey Buzzard & Pernis ptilorhynchus & $P$ & $P$ & $\mathrm{~N}$ \\
\hline 15 & Bonelli's Eagle & Aquila fasciata & $\mathrm{N}$ & $P$ & $P$ \\
\hline 16 & Pallas's Fish Eagle & Haliaeetus leucoryphus & $\mathrm{N}$ & $\mathrm{N}$ & $\mathrm{N}$ \\
\hline 17 & Tawny Eagle & Aquila rapax & $\mathrm{N}$ & $P$ & $\mathrm{~N}$ \\
\hline 18 & Crested Serpent Eagle & Spilornis cheela & $\mathrm{P}$ & $\mathrm{P}$ & $P$ \\
\hline 19 & Changeable Hawk Eagle & Nisaetus cirrhatus & $\mathrm{N}$ & N & $P$ \\
\hline 20 & Common Kestrel & Falco tinnunculus & $P$ & $\mathrm{P}$ & $\mathrm{P}$ \\
\hline 21 & Eurasian Hobby & Falco subbuteo & $\mathrm{N}$ & N & $\mathrm{N}$ \\
\hline 22 & Laggar Falcon & Falco jugger & N & $P$ & $\mathrm{~N}$ \\
\hline 23 & Red-necked Falcon & Falco chicquera & N & $P$ & $\mathrm{~N}$ \\
\hline 24 & Spotted Owlet & Athene brama & $P$ & $P$ & $P$ \\
\hline 25 & Western Barn Owl & Tyto alba & P & $\mathrm{P}$ & $\mathrm{N}$ \\
\hline 26 & Dusky Eagle Owl & Bubo coromandus & $P$ & $N$ & $\mathrm{~N}$ \\
\hline 27 & Brown Fish Owl & Ketupa zeylonensis & $P$ & $P$ & $P$ \\
\hline 28 & Indian Scops Owl & Otus bakkamoena & $P$ & $P$ & $\mathrm{~N}$ \\
\hline 29 & Mottled Wood Owl & Strix ocellata & $N$ & $P$ & $\mathrm{~N}$ \\
\hline 30 & Indian Eagle-Owl & Bubo bengalensis & $\mathrm{N}$ & $\mathrm{N}$ & $\mathrm{N}$ \\
\hline
\end{tabular}

if these are migrants from other parts of the semi-arid biogeographic zone or the adjoining geographic regions.

e) Out of the 30 raptor species presented in this work from NCS-Kuno, we didn't find reports of 11 species in RTR and two species in STR. The species not reported from STR are the Black Kite and Dusky Eagle Owl. The species not reported from RTR are the Bonelli's Eagle, Western Marsh Harrier, Egyptian Vulture, White-rumped Vulture, Laggar Falcon, Western Osprey, Red-necked Falcon, Tawny Eagle, White-eyed Buzzard, Griffon Vulture, and Mottled Wood Owl. f) Raptors are known to have long home ranges, and they may be flying to NCS-Kuno for food. Besides, Chambal forms confluences with other perennial tributaries like Kali-Sindh, Parbati, and Banas upstream, and the confluence of five rivers around Pachhnada in the downstream. Future studies may further reveal the relationship between the home range of different raptor species and the riverine habitat. 


\section{RECOMMENDATIONS}

The National Chambal Sanctuary, which constitutes a part of river Chambal, is included under wetland types 11 (rivers, streams - slow-flowing, lower perennial) \& 12 (rivers, streams - fast-flowing, upper perennial) (Scott 1989). As a protected area of national stature, river Chambal is provided with incidental conservation benefits for avian diversity. The river plays a crucial role in supporting local stork populations as well as giving alternate refuge for local migrants during the years with extreme ecological conditions (Sharma \& Singh 2018). Similarly, continuous monitoring of wetland habitats in and outside Chambal may highlight the kind of ecological attraction Chambal holds for the skimmer populations of other wetlands in the region (Singh \& Sharma 2018).

\section{Consideration for the tri-state Chambal Ramsar site}

Based on field surveys we have reported in the past on the status and population trends of large shorebirds and Raptor species of NCS (Sharma \& Singh 1986; Sharma et al. 1995, 2013). The wetland and the adjoining area of the National Chambal Sanctuary form the habitat for many resident and migratory bird species, of which some are globally threatened. Our study on raptors identifies nine of the thirty raptors under the migratory category, attracted to the wetland landscape of NCS. A detailed study on the migration pattern of raptors and large shorebirds to River Chambal may further highlight the need for improved attention to river Chambal as a tristate Ramsar site of India. Madhya Pradesh has already initiated the proposal some years back and deserves coordination at the national level.

\section{Review of Scheduled status for three species of raptors}

As predators, the raptors form one of the top links in the ecological chain and are, therefore, indicators of the health of the environment (Naoroji 2011). Among the most effective predators, the birds of prey keep a constant check on the population of amphibians, reptiles, mammals, and birds, and even on themselves. Found in diverse habitats, they are among the first that are affected by chemical pollution, adverse exploitation, and an overall decline of the habitat. The results from the present study on raptors propose that the MoEFCC consider reviewing the status given under the Wildlife (Protection) Act to Cinereous Vulture Aegypius monachus, Egyptian Vulture Neophron percnopterus, and Red-headed Vulture Sarcogyps calvus.

\section{A comprehensive study on raptors of Arid Biogeographic Region / Khathiar-Gir Eco Region}

Studies on tiger by Reddy et al. (2012) have already suggested on-ground gene-pool continuity over RTR and Sawai Madhopur National Park (MNP), which are in Rajasthan on the northern side of NCS and the KunoPalpur Wildlife Sanctuary (KPWS) of Madhya Pradesh on the southern side of NCS. Only a future study on raptors would further confirm the nature of ecological connectivity of habitats on either side of the National Chambal Sanctuary through the air.

We expect some of the raptors in NCS are visitors from the adjoining habitats of Rajasthan and Madhya Pradesh, within the dry deciduous forest ecoregion. Tharmalingam et al. (2011) reported the presence of 19 raptor species in Kuno-Palpur of Madhya Pradesh, and the list doesn't show the presence of 16 raptors observed in our present list (Table 3). However, out of these 16 species, six are reported from Ranthambhore Tiger Reserve (RTR) and nine from Sariska Tiger Reserve (STR). The observations suggest some continuity in the distribution of raptors in the north and south of river Chambal.

The list of raptor birds given in the present study forms a base for time-related comparison of speciesavailability and for an impact assessment. It is urged, that detailed studies may be promoted on raptors seen in National Chambal Sanctuary and their possible home ranges extending through other perennial tributaries and forest habitats like those of Kuno and Shivpuri in Madhya Pradesh, and Ranthambhore and Sariska in Rajasthan.

\section{REFERENCES}

Anonymous (2021). Birds of Ranthambhore: http//www. ranthambhoreguides.com/birds/checklist, Download 22nd March 2021.

Ali, S. (1979). The Book of Indian Birds. Eleventh Edition. Bombay Natural History Society, Bombay. Pp xlvii + 187.

Ali, S. (2002). The Book of Indian Birds. Thirteenth Edition Revised. Bombay Natural History Society, Oxford University Press. Pp Ivii + 326.

Bildstein, K.L., W. Schelsky, J. Zalles \& S. Ellis (1998). Conservation status of tropical raptors. Journal of Raptor Research 32(1): 3-18.

Bustard, H. R. (1999). Indian Crocodile Conservation Project. Pages 5-9. Envis (Wildlife and Protected Areas) 2(1): . Wildlife Institute of India, Dehradun. Pp 1-155.

Choudhary B. C. Gautam, P. \& Nair. T. (2014). Generic tri-state management plan. National Chambal sanctuary, National tri-state Chambal sanctuary management and co-ordination committee (NTRIS - CASMACC) Ministry of environment and Forests, Government of India.

de Vos, A. (1984). Crocodile Conservation in India. Biological Conservation 29 (1984): 183-189. 

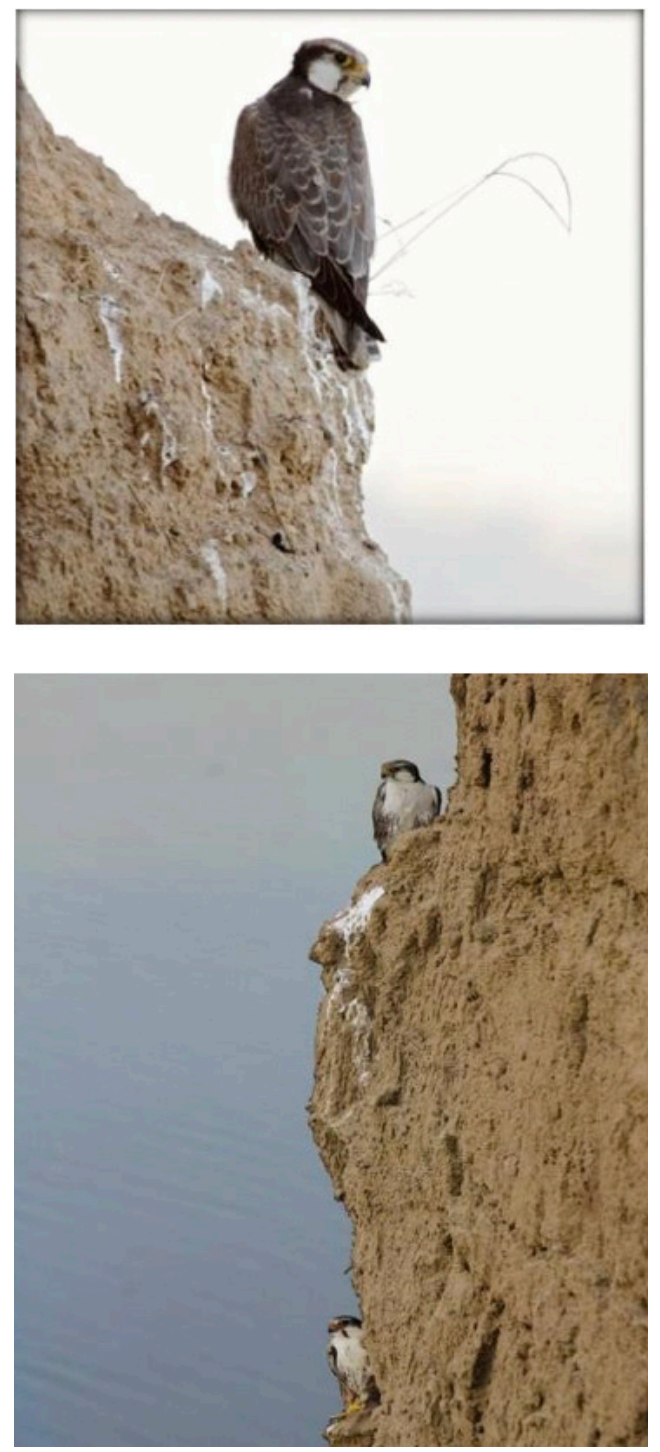

Image 1. Top. Laggar Falcon Falco jugger at Jetpur, river Chambal (3 $\mathrm{km}$ upstream from study zone-VII Rajghat). Above. Ravine cliff facing river Chambal, used by Laggar Falcon pair at Jetpur. () Udayan

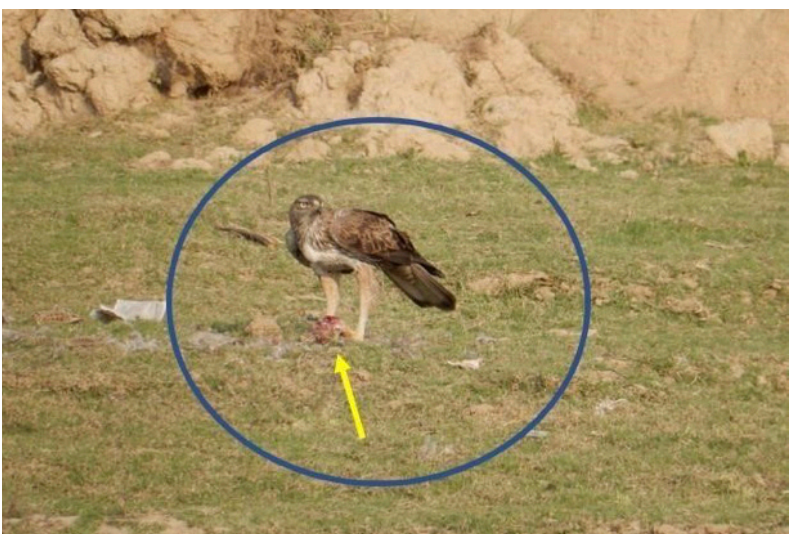

Image 4. Bonelli's Eagle eating a bird, at Barsala $(48 \mathrm{~km}$ downstream from Rajghat, study zone- VIII). @ R.K. Sharma

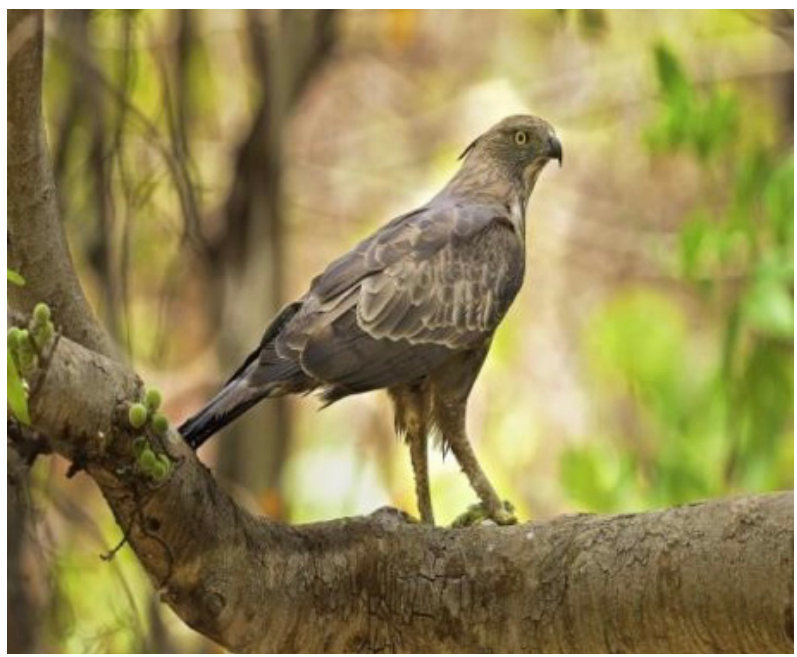

Image 2. Changeable Hawk Eagle Nisaetus cirrhatus at Ker Kho in Palpur Kuno WS. @ Udayan

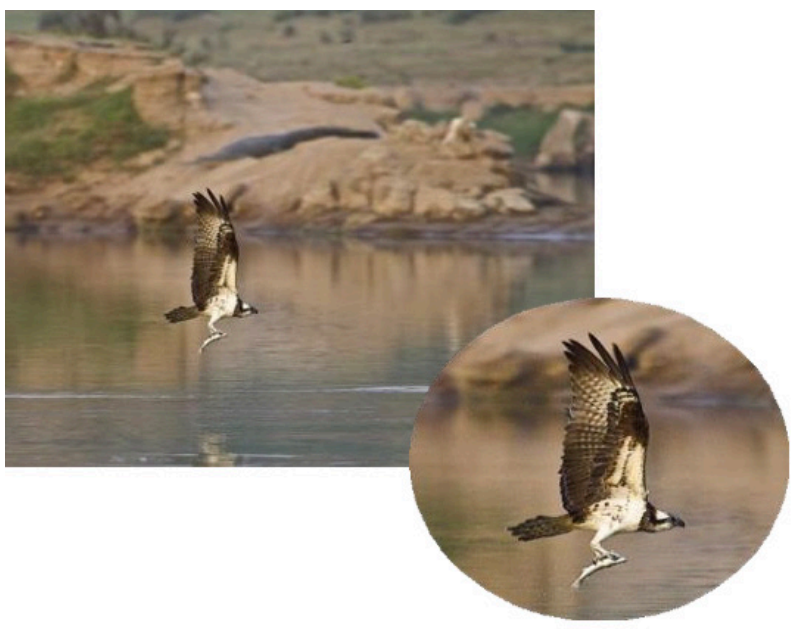

Image 3. Osprey Pandion haliaetus while lifting a fish out of water at Daljit Singh ka Pura, river Chambal, seen with a Gharial Gavialis gangeticus in the background returning to water after nesting. The location is in study zone-VIII, 45 km downstream Rajghat. @ Udayan

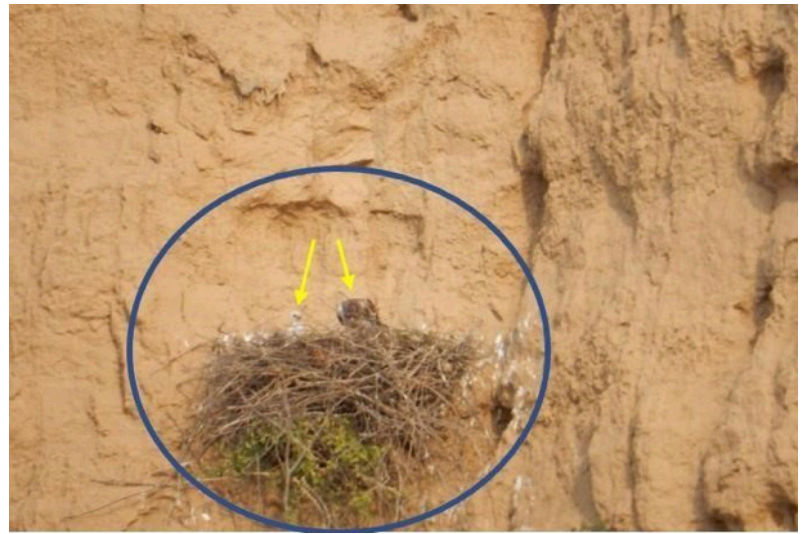

Image 5. Bonelli's Eagle adult with chick at nest built on the ravine facing river Chambal, Chakarnagar in study zone-XII. @ R.K. Sharma 


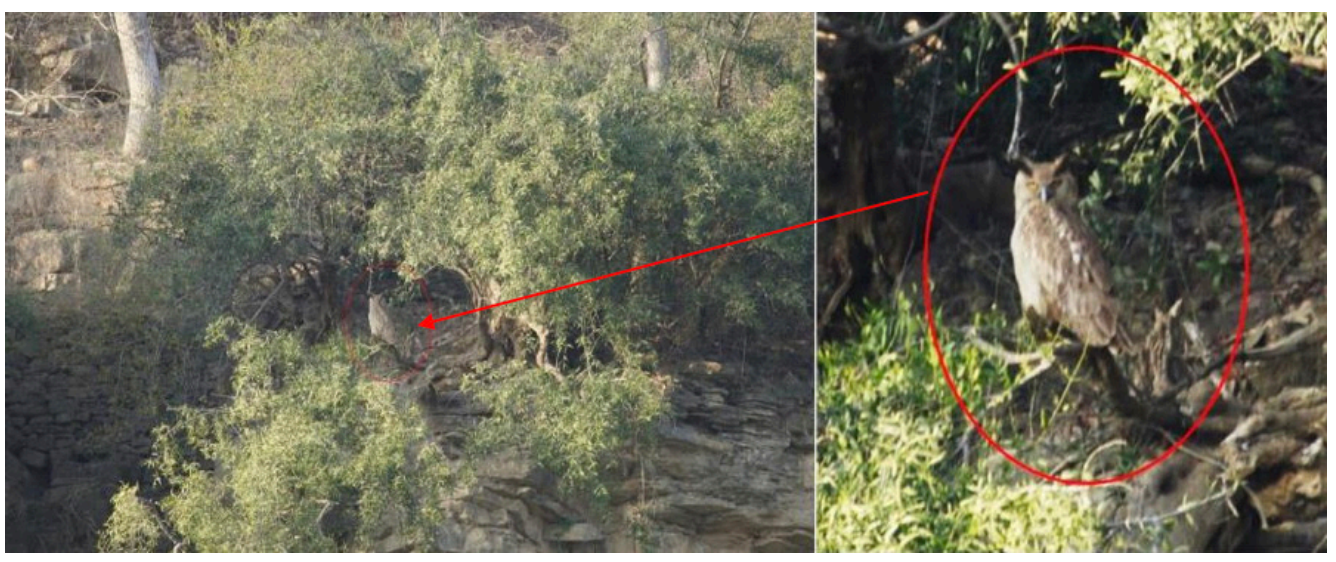

Image 6. Dusky Eagle Owl Bubo coromandus at Baroli (study zone-III) on Rajasthan bank of Chambal close to Ranthambhore Tiger Reserve and Kaila Devi Wildlife Sanctuary. @ Udayan

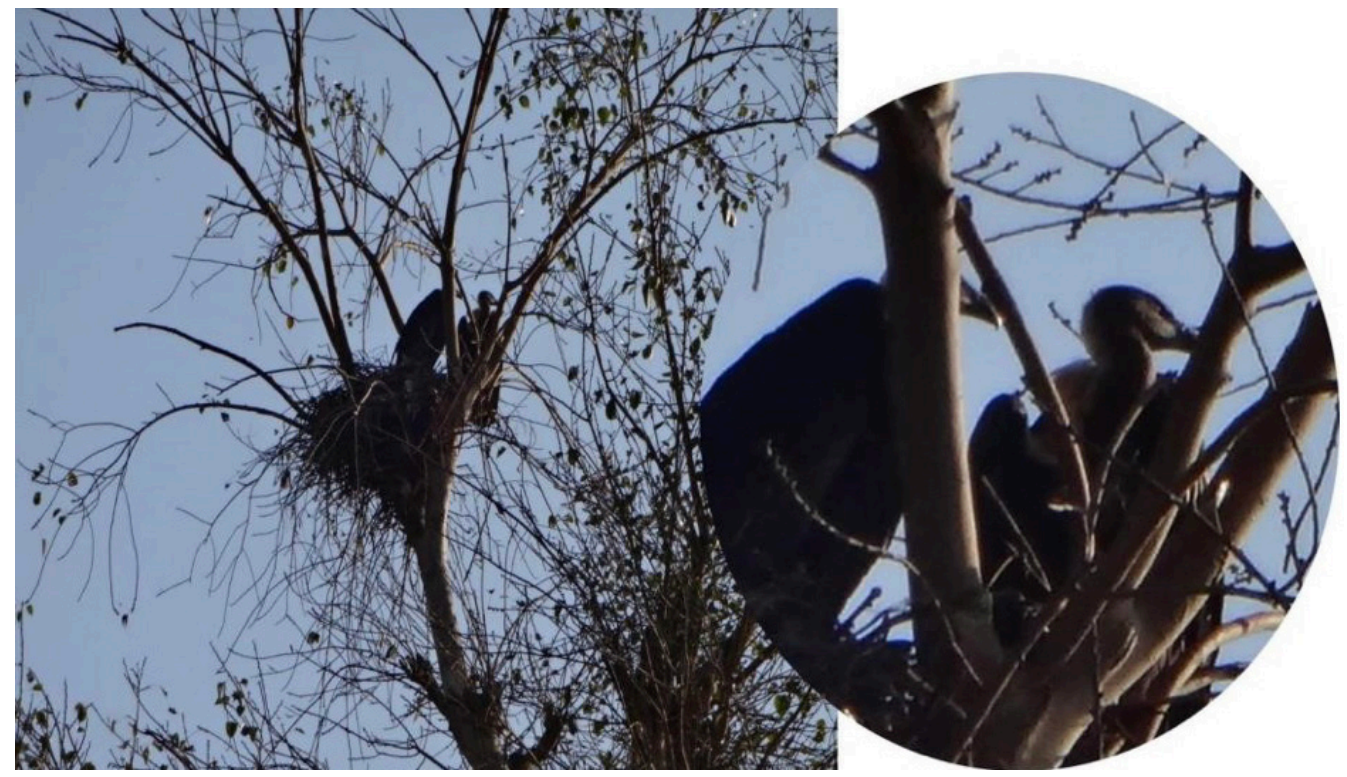

Image 7. Vultures at nest along Kuno. @ R.K. Sharma

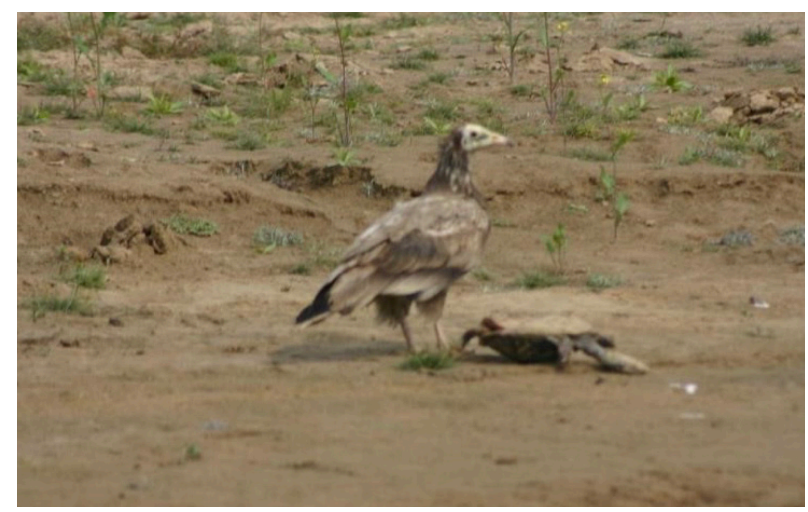

Image 8. Egyptian Vulture at Tigri Rithaura in study zone-VII while feeding on carcass of Emydid Turtle in National Chambal Sanctuary. (c) R.K. Sharma 

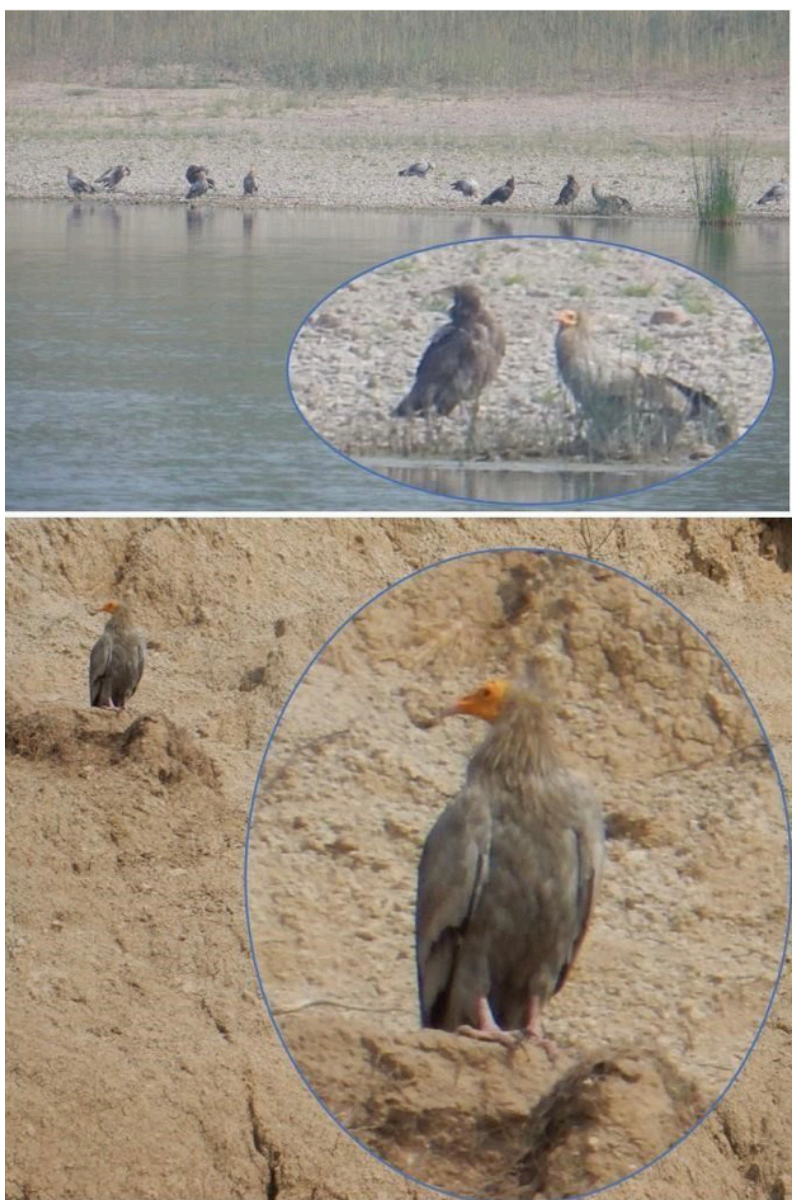

Image 9. Egyptian Vultures downstream Rajghat at Daljit ka Pura (Study zone-VIII). Immature Egyptian Vultures are distinguishable from their darker body. (C) R.K. Sharma

ENVIS (2020). Protected Areas of India www.wiienvis.nic.in/ updated 03 August 2020. Downloaded 20 March 2021.

FSI (2019). The State of Forest Report 2019. Forest Survey of India, Ministry of Environment and Forest, Dehra Dun. Pp 1-167.

Gill F., D. Donsker \& P. Rasmussen (Eds). (2021). IOC World Bird List (v11.1). Accessed 28 Feb 2021. https://doi.org/10.14344/IOC. ML.11.1

Gopi, G. V. \& B. Pandav (2006). White bellied sea-eagle Haliaeetus leucogaster preying on salt-water crocodile Crocodylus porosus. Indian Birds 2(6): 171.

Grimmett, R., C. Inskipp, \& T. Inskipp (2011). Birds of the Indian subcontinent. India: Oxford, 528pp.

Hernández, Mauro \& Antoni Margalida (2009). Poison-related mortality effects in the endangered Egyptian vulture (Neophron percnopterus) population in Spain. August 2009, European Journal of Wildlife Research 55(4):415-423. https://doi.org/10.14344/IOC. ML.11.110.1007/s10344-009-0255-6

Meteyer, C.U., B. A. Rideout, H. L. Shivasprasad, S. Ahmed, M. J. I. Chaudry, M. Arshad, S. Mahmood, A. Ali, \& A. A. Khan (2004). Diclofenac residues as the cause of vulture population declines in Pakistan. Nature 427: 630-633.

Mitra (1979). Checklist of Birds in National Chambal Sanctuary Unpublished official report.

Murthy, R. S. (2004). Management Plan of National Chambal Sanctuary, Morena (M.P.) 2003-2004 to 2013-2014. Forest Department,
Government of Madhya Pradesh, Bhopal, India, 148pp.

Nair, T. \& Y. C. Krishna (2013). Vertebrate fauna of the Chambal River Basin, with emphasis on the National Chambal Sanctuary, India. Journal of Threatened Taxa 5(2): 3620-3641. https://doi. org/10.11609/JoTT.o3238.3620-41

Naoroji Rishad (2011). Birds of prey of the Indian subcontinent. Om books international corporate \& editorial. www.ombooks.com, 692pp.

Palei, N. C., B. P. Rath \& B. P. Acharya (2019). An observation of the White-Bellied Sea Eagle Haliaeetus leucogaster preying on Saltwater Crocodile Crocodylus porosus in Bhitarkanika Wildlife Sanctuary, India. Journal of Threatened Taxa, Vol.11, Number 13: 1476714769. https://doi.org/10.11609/jott.4916.11.13.14767-14769

Potier, S., M. Mitkus \& A. Kelber (2020). Visual adaptations of diurnal and nocturnal raptors. Seminars in Cell and Developmental Biology, https://doi.org/10.1016/j.semcdb.2020.05.004

Prakash, V., D. J. Pain, A. A. Cunningham, P. F. Donald, N. Prakash, A. Verma, R. Gargi, S. Sivakumar \& A. R. Rahmani (2003). Catastrophic collapse of Indian white-backed Gyps bengalensis and long-billed Gyps indicus vulture populations. Biological Conservation 109: 381-390

Rao, R.J. \& L.A.K. Singh (1987a). Notes on comparative body size, reproductive effort and species of Kachuga (Reptilia, Chelonia) in the National Chambal Sanctuary. Journal of the Bombay Natural History Society 84(1): 55-65.

Rao, R.J. \& L.A.K. Singh (1987b). Notes on ecological relationship in basking and nesting site utilisation among Kachuga spp. (Reptilia, Chelonia) and Gavialis gangeticus (Reptilia, Crocodilia) in National Chambal Sanctuary. Journal of the Bombay Natural History Society 84(3): 599-604.

Rao, R.J. \& L.A.K. Singh (1987c). Kachuga (Reptilia, Emydidae) in National Chambal Sanctuary: Observations on diurnal nesting emergences and unsuccessful nesting crawl. Journal of the Bombay Natural History Society 84(3): 688-691.

Reddy P. A., D. S. Gour, M. Bhavanishankar, K. Jaggi, S.M. Hussain, K. Harika \& S. Shivaji (2012). Genetic Evidence of Tiger Population Structure and Migration within an isolated and fragmented landscape in Northwest India. PLoS ONE 7(1): e29827. https://doi. org/10.1371/journal.pone.0029827

Rodgers, W.A. \& H.S. Panwar (1988). Planning a Wildlife Protected Area Network in India. A report prepared for the Ministry of Environment and Forests and Wildlife, Government of India, volumes 1 and 2 . 339, 267.

Sale, J. B. (1982). 2nd Draft. Management Plan for the National Chambal Sanctuary. First Five-Year Period 1982/83 - 1986/87. Central Crocodile Breeding and Management Institute, Hyderabad, iii+82pp.

Scott, D.A. [ed.] (1989). A Directory of Asian Wetlands. IUCN, Gland, Switzerland, and Cambridge, UK, xiv+1181pp, 33 maps.

Sharma, R.K. \& L.A.K. Singh (1986). Wetland Birds in National Chambal Sanctuary. Preliminary Report from field camp. Crocodile Research Centre of Wildlife Institute of India, Hyderabad, 36pp+7table.

Sharma, R.K. \& L.A.K. Singh (2014). Status of Gangetic Dolphin (Platanista gangetica) in National Chambal Sanctuary after thirty years. Zoos' Print Magazine XXIX (7): 22-27.

Sharma, R.K. \& L.A.K. Singh (2015). Status of Mugger Crocodile (Crocodylus Palustris) in National Chambal Sanctuary after thirty years and its implications on conservation of Gharial (Gavialis Gangeticus). Zoos' Print Magazine XXX (5): 9-16.

Sharma, R. K. \& L.A.K. Singh (2018). Spatial and temporal patterns of stork sightings (Aves: Ciconiidae) in National Chambal Sanctuary of Gangetic River system. Journal of Threatened Taxa 10(3): 1141011415. http://doi.org/10.11609/jott.3817.10.3.11410-11415

Sharma, R.K., R. Mathur \& S. Sharma (1995). Status and Distribution of fauna in National Chambal Sanctuary, Madhya Pradesh. The Indian Forester, Dehradun, 121(10): 912-916.

Sharma, R. K., S. C. Bhadoria, B. S. Rathore \& N. Dasgupta (2013). Diversity of aquatic animals in National Chambal Sanctuary, Madhya Pradesh, pp. 246-261. In: Rathore, B.S. \& V.S. Rathore 
(eds.) Management Resource for Sustainable Development. Divya Publishing House, Astral International Pvt. Ltd, New Delhi, 306pp.

Shultz, S., Baral, H.S., Charman, S., Cunningham, A.A., Das, D., Ghalsasi, G.R., Goudar, M.S., Green, R.E., Jones, A., Nighot, P., Pain, D.J. \& Prakash, V. (2004). Diclofenac poisoning is widespread in declining vulture populations across the Indian subcontinent. Proceedings of the Royal Society of London B, (Supplement) 271: S458-S460. https://doi.org/10.1098/Rsbl.2004.0223

Singh, L.A.K. \& R. J. Rao (1984). Ecological relationship among Turtles in National Chambal Sanctuary. Interim Study Report-1 CRC/ NCS/21-a.Crocodile Research Centre. Wildlife Institute of India. Morena, 45pp.

Singh, L.A.K. \& R. J. Rao (1985). Ecological Relationship among Turtles in National Chambal Sanctuary, Interim Study Report-2. National Chambal Sanctuary, Deori, Morena, Madhya Pradesh, 27pp.

Singh, L.A.K. \& R. K. Sharma (1985). Gangetic Dolphin (Platanista gangetica) observations on habits and distribution pattern in National Chambal Sanctuary. Journal of the Bombay Natural History Society 82(3): 648-653.

Singh, L.A.K. \& R. K. Sharma (2015). Climate-related warnings viewed through population trend of crocodiles and dolphin in National Chambal Sanctuary. Presentation made at and Abstract in: UGCSAP Sponsored National Seminar on Challenges and practices in biodiversity conservation with special reference to herpetofauna, 20-21 November 2015, Department of Zoology, North Orissa University.

Singh, L.A.K. \& R. K. Sharma (2018). Sighting trend of the Indian Skimmer (Charidiformes: Laridae: Rynchops albicollis Swainson, 1838) in National Chambal Gharial Sanctuary (1984-2016) reflecting on the feasibility of long-term ecological monitoring. Journal of Threatened Taxa 10(5): 11574-11582. http://doi.org/10.11609/ jott.3732.10.5.11574-11582

Singh, L.A.K. (1979). Results of survey on the status of mugger crocodile (Crocodylus palustris Lesson) in rivers Budhabalanga West Deo in Similipal Tiger reserve, Orissa. Typed Report, Dec. 1979. Similipal Tiger Reserve, Jashipur.

Singh, L.A.K. (1985). Gharial Population Trend in National Chambal Sanctuary with notes on radio- tracking. Study Report December 1985. Crocodile Research Centre, Wildlife Institute of India, Hyderabad, 167pp+vii.

Singh, L.A.K. (1999). Status of Gharial and Mugger in Orissa, pp. 1723. In: Indian Crocodiles. Envis (Wildlife and Protected Areas). Vol.2, No.1, Wildlife Institute of India, Dehra Dun, June 1999, 155pp.

Singh, L.A.K. (1993). Survey of Raptors seen in Simlipal Tiger Reserve, Orissa. Bihang newsletter, Vol. 1 (2), January - February 1993: 5-6.

Sultana, A. (2013). An updated checklist of birds of Sariska Tiger Reserve, Rajasthan, India. Journal of Threatened Taxa 5(13): 47914804. http://doi.org/10.11609/JoTT.03215.4791-804

Swan, G.E., Cuthbert, R., Quevedo, M., Green, R.E., Pain, D.J., Bartels, P., Cunningham, A.A., Duncan, N., Meharg, A.A., Oaks, J.L., Parry-Jones, J., Shultz, S., Taggart, M.A., Verdoorn, G. \& Wolter, K. (2006a). Toxicity of diclofenac to Gyps vultures. Biology Letters 2:279-282.
Swan, G., Naidoo, V., Cuthbert, R., Green, R.E., Pain, D.J., Swarup, D., Prakash, V., Taggart, M., Bekker, L., Das, D., Diekmann, J., Diekmann, M., Killian, E., Meharg, A., Patra, R.C., Saini, M. \& Wolter, K. (2006b). Removing the threat of diclofenac to critically endangered Asian vultures 2006. Public Library of Science Biology 4: 396-402.

Tharmalingam, R., N. Shridharan \& R. Kalle (2011). Birds of Kuno Wildlife Sanctuary, Central India, Zoos' Print, vol. XXVI, Issue-12 Dec. 2011.

Vyas, R.V. (2019). Note on interactions between predators and prey: Indian crocs and birds. Crocodile Specialist Group, Newsletter 38(2): 4-7.

Wikipedia 2021. Khathiar-Gir dry deciduous forests. Last edited on 26 January 2021. Accessed 19 March 2021. https://en.wikipedia.org/ wiki/Khathiar-Gir_dry_deciduous_forests

WWF (2021). Southern Asia: Northwestern India, Ecoregions. Downloaded on 19 April 2021 from https://www.worldwildlife.org/ ecoregions/im0206

Zabala-Albizua, Jabi, Joel C. Trexler, Nilmini Jayasena \& Peter Frederick (2020). Early Breeding Failure in Birds Due to Environmental Toxins: A Potentially Powerful but Hidden Effect of Contamination. October 2020, Environmental Science and Technology 54(21): 13786-13796. https://doi.org/10.1021/acs.est.0c04098

\section{सारांश}

राष्ट्रीय चंबल अभ्यारण्य (NCS) में शिकारी पक्षी (रैपटर्स) महत्व रखते हैं क्योंकि वे इस क्षेत्र के शीर्ष शिकारी पक्षियों में से हैं, जो छोटे मगरमच्छों, कछुओं और अन्य पक्षियों का शिकार करते हैं। राप्टर्स की 30 प्रजातियों की हमारी चेकलिस्ट 1983 और 2016 के बीच शीतकालीन सर्वेक्षणों के दौरान किए गए अवलोकनों से विकसित की गई है। इस अवधि में हमने जिस क्षेत्र में सर्वेक्षण किया उसके अंतर्गत राष्ट्रीय चंबल अभ्यारण्य और चंबल कूनो नदी के संगम के क्षेत्र मध्य प्रदेश सीमा में आते हैं। चंबल परिद्धश्य के बीहड़ की खड़ी और दुर्गम मिट्टी चट्टानों का उपयोग करने हेतु जो शिकारी पक्षी पहचाने गए हैं उनमें बॉनलीज ईगल, लागर फाल्कन, इजिप्शियन वल्चर, व्हाइट रैम्पड वल्चर, स्पॉटेड आउलेट, इंडियन ईगल आउल आदि अन्तर्भुक्त हैं । राष्ट्रीय चंबल अभ्यारण्य में वर्णित अधिकांश अन्य रैपटर्स क्रमशः राजस्थान एवं मध्य प्रदेश के आसपास के वन्यजीव क्षेत्रों से तथा समीपवर्ती क्षेत्रों के आगंतुक माने जाते हैं । वर्गीकरण के दो तरीकों के अनुसार यह इलाका अर्ध शुष्क जैव भौगोलिक क्षेत्र या खाटिहार गिर शुष्क पर्णपाती वन क्षेत्र में आता है । एनसीएस-कूनो की सूची की तुलना पिछली रिपोर्ट्स एवं राजस्थान की सरिस्का टाइगर रिजर्व और रणथंबोर टाइगर रिजर्व के लिए उपलब्ध सूची से की गई है। वर्तमान कार्य एनसीएस में वर्ष 1983 से प्रारंभ किए गए घड़ियाल (गेवियलिस गैंजेटिकस) एवं अन्य जलीय जीवो की दीर्घकालीन परिस्थिति की निगरानी का परिणाम है। शिकारी पक्षियों को देखने के लिए पानी की सतह एवं तटरेखा से और दूर तक देखने के लिए समय और ध्यान देने की जरुरत मांग की है। फिर भी, 34 वर्षों में बनाए गए हमारे सावधानीपर्वक रिकॉर्ड के एक बुनियादी रूपरेखा तैयार की है, जो उन मापदंडों पर केंद्रित अध्ययनों को क्रियान्वित करने के लिए प्रेरित करती है जो एनसीएस के आसपास के वन आवासों और वन्यजीव अभ्यारण्य के पारिस्थितिक तंत्र को बनाए रखते हैं। 
ᄒᄒ

들

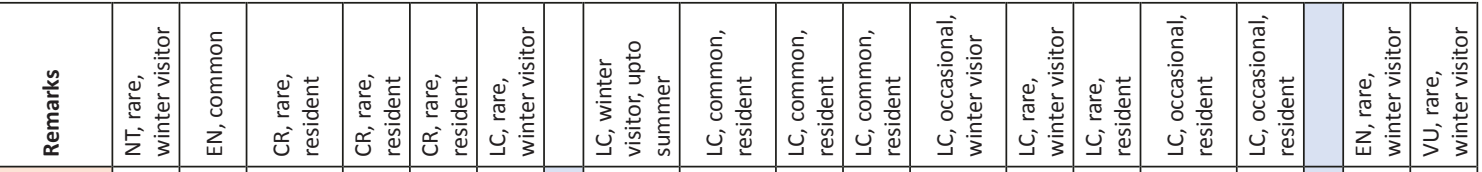

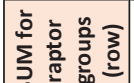

in

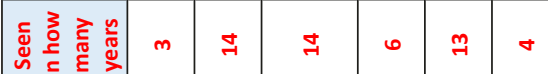
J

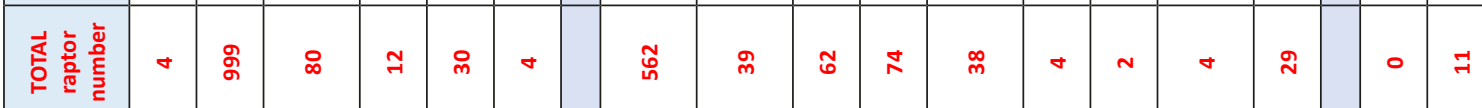

\begin{tabular}{|c|c|c|c|c|c|c|c|c|c|c|c|c|c|c|c|c|c|c|c|}
\hline 9т0z & $z$ & 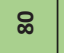 & $\sigma$ & $z$ & $N$ & $z$ & $m$ & ఉ్ & $\sigma$ & $z$ & 0 & 0 & $z$ & $z$ & $-r$ & in & 0 & $z$ & $N$ \\
\hline stor & $z$ & 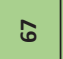 & $a$ & N & $\sigma$ & $-r$ & in & ก & n & $\sigma$ & $\infty$ & $m$ & $z$ & $z$ & $z$ & $m$ & 0 & $z$ & $z$ \\
\hline
\end{tabular}

\begin{tabular}{|c|c|c|c|c|c|c|c|c|c|c|c|c|c|c|c|c|c|c|c|}
\hline & $z$ & 6 & $\sigma$ & $N$ & $\sigma$ & $\pi$ & in & กี & n & $\sigma$ & $\infty$ & $m$ & $z$ & $z$ & $z$ & $m$ & 0 & $z$ & \\
\hline tтоz & $H$ & ब & 0 & $z$ & - & $z$ & $\sigma$ & $\tilde{m}$ & n & $N$ & $n$ & -1 & - & z & -1 & $\sigma$ & $\infty$ & z & z \\
\hline
\end{tabular}

\begin{tabular}{|c|c|c|c|c|c|c|c|c|c|c|c|c|c|c|c|c|c|c|c|}
\hline & & & & & & & & & & & & & & & & & & & \\
\hline દtoz & $z$ & $\overrightarrow{0}$ & in & $z$ & $m$ & $z$ & m & in & $m$ & $z$ & 0 & $N$ & $z$ & -1 & $z$ & N & • & $z$ & $z$ \\
\hline zт0z & $z$ & 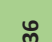 & o & 7 & 7 & -1 & m & n & 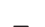 & 0 & 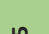 & 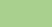 & 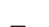 & 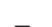 & & 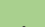 & & 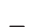 & . \\
\hline
\end{tabular}

\begin{tabular}{|c|c|c|c|c|c|c|c|c|c|c|c|c|c|c|c|c|c|c|c|}
\hline ztor & $z$ & $\stackrel{m}{\circ}$ & $\sigma$ & $z$ & $z$ & $\rightarrow$ & $m$ & ผ & $z$ & 0 & in & - & $z$ & $z$ & $z$ & $\sigma$ & in & $z$ & N \\
\hline โтог & $z$ & $\infty$ & $m$ & N & N & $z$ & $\sigma$ & ดิ & $z$ & $z$ & $\sigma$ & $N$ & $z$ & $z$ & $z$ & $N$ & $\sigma$ & $z$ & $z$ \\
\hline
\end{tabular}

\begin{tabular}{|c|c|c|c|c|c|c|c|c|c|c|c|c|c|c|c|c|c|c|}
\hline otoz & - & N & $N$ & $-r$ & $\rightarrow$ & $z$ & in & จิ & $\theta$ & $a$ & in & $N$ & $z$ & $z$ & $z$ & $r$ & 0 & $z$ \\
\hline $600 z$ & $z$ & - & $\nabla$ & $z$ & $N$ & $z$ & $m$ & 움 & 0 & $z$ & 6 & in & $z$ & $z$ & $z$ & $N$ & in & $z$ \\
\hline
\end{tabular}

\begin{tabular}{|c|c|c|c|c|c|c|c|c|c|c|c|c|c|c|c|c|c|c|c|}
\hline 8002 & $z$ & 8 & n & $z$ & $\sigma$ & $-\pi$ & ब & $\vec{n}$ & in & a & r & 0 & $z$ & $z$ & $z$ & $\sigma$ & 0 & $z$ & $N$ \\
\hline$\angle 00 z$ & $z$ & $\approx$ & 0 & $\theta$ & $\approx$ & 7 & + & & & 7 & & & & & & 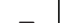 & & $z$ & $z$ \\
\hline
\end{tabular}

\begin{tabular}{|c|c|c|c|c|c|c|c|c|c|c|c|c|c|c|c|c|c|c|c|}
\hline$\angle 00 z$ & $z$ & $N$ & 0 & $N$ & $N$ & z & $\nabla$ & in & $z$ & $z$ & $\sigma$ & $\sigma$ & $z$ & $z$ & $z$ & & m & $z$ & $z$ \\
\hline $900 z$ & $z$ & $\infty$ & $\infty$ & $z$ & $\sigma$ & - & $\sigma$ & రి & $z$ & $\approx$ & in & $-r$ & $N$ & $z$ & $H$ & $z$ & 0 & $z$ & $z$ \\
\hline
\end{tabular}

\begin{tabular}{|c|c|c|c|c|c|c|c|c|c|c|c|c|c|c|c|c|c|c|c|}
\hline $500 z$ & $N$ & స్తి & $a$ & $N$ & $N$ & z & n & $\vec{\pi}$ & $N$ & $z$ & $m$ & $m$ & $z$ & -1 & $z$ & $z$ & in & $z$ & $\sigma$ \\
\hline to0z & $z$ & $\stackrel{్}{~}$ & n & $z$ & -1 & $z$ & $m$ & $\stackrel{\sim}{m}$ & $m$ & $\overrightarrow{7}$ & $N$ & $N$ & 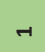 & $z$ & -1 & z & $n$ & $z$ & $z$ \\
\hline$\varepsilon 00 z$ & $z$ & $\tilde{\sigma}$ & $\infty$ & $m$ & $\sim$ & $z$ & d & $\hat{N}$ & $z$ & $\infty$ & $r$ & & $z$ & $z$ & 7 & & $\theta$ & $z$ & 7 \\
\hline
\end{tabular}

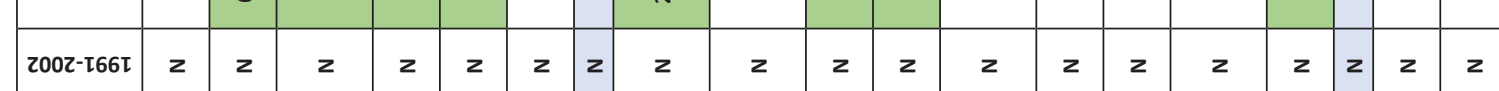

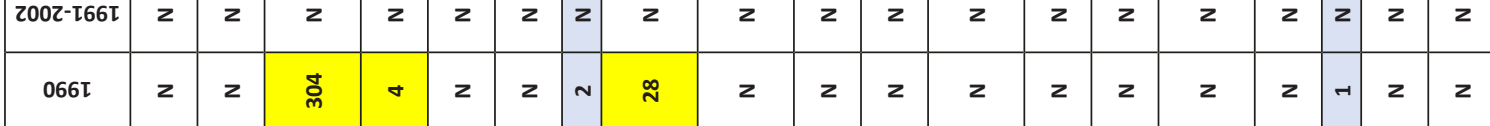

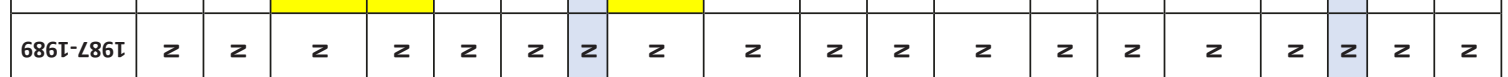

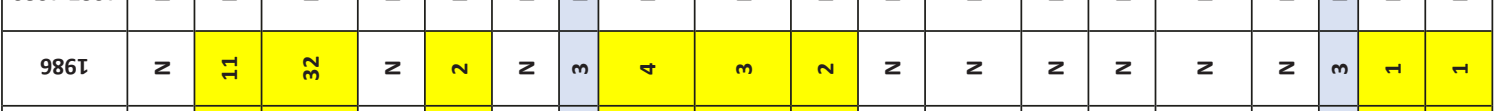

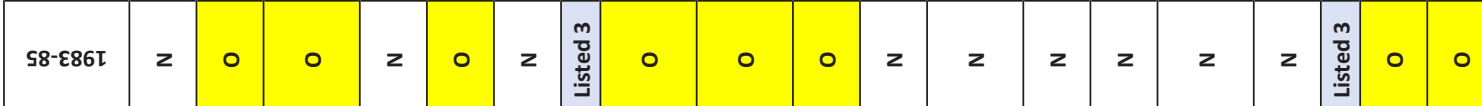

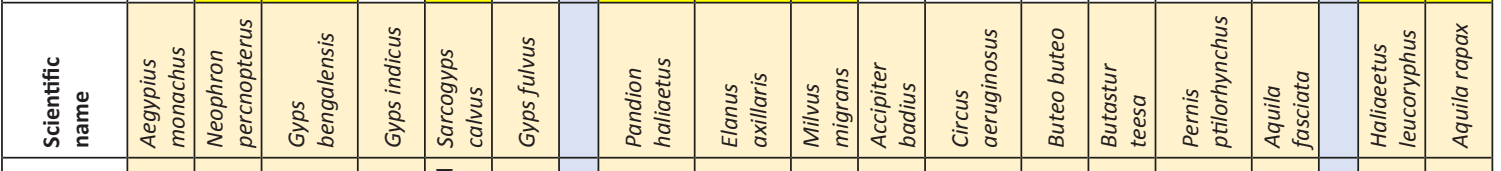

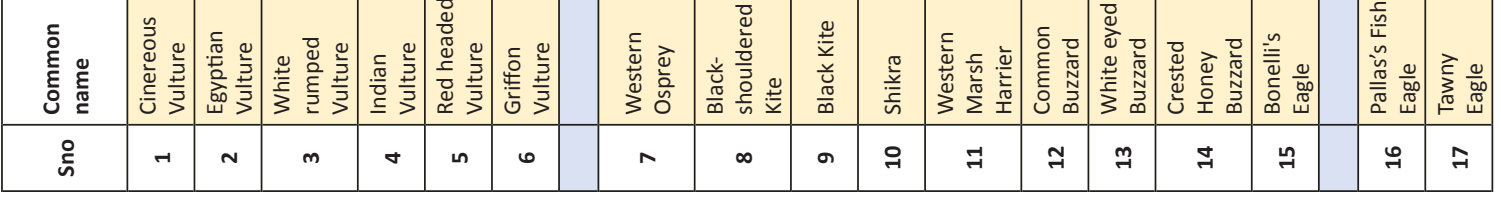




\begin{tabular}{|c|c|c|c|c|c|c|c|c|c|c|c|c|c|c|c|c|c|c|c|}
\hline 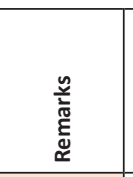 & 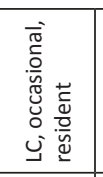 & 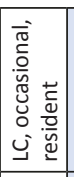 & & 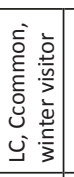 & 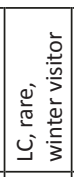 & 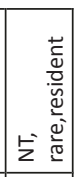 & 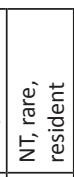 & & 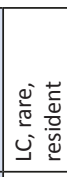 & 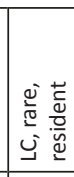 & 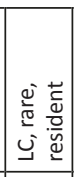 & 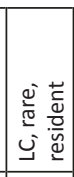 & 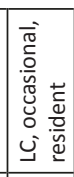 & 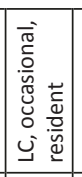 & 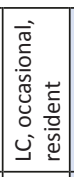 & & & & \\
\hline 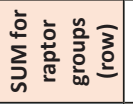 & & & $m$ & & & & & $\mid \begin{array}{l}0 \\
\mid\end{array}$ & & & & & & & & ని & & จे & \\
\hline 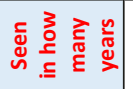 & $\sigma$ & $\sigma$ & & ㅇ & 0 & $m$ & $n$ & & $\sigma$ & $\sigma$ & $\sigma$ & $\sigma$ & in & $\sigma$ & $\sigma$ & & : & ฉి & รे \\
\hline 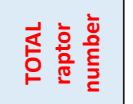 & in & in & & ని & 6 & $\hat{N}$ & $\sigma$ & & $\sigma$ & in & $\sigma$ & in & $r$ & in & in & & ڤ̊ํํ & ڤ̊ํํ & 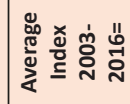 \\
\hline 9102 & $z$ & $z$ & - & $\sigma$ & $z$ & $\sim$ & 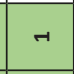 & $m$ & $z$ & -1 & $z$ & $z$ & 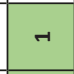 & $z$ & $z$ & $\sim$ & $\stackrel{7}{7}$ & $\stackrel{m}{m}$ & $\stackrel{n}{9}$ \\
\hline stor & - & -1 & N & 0 & -1 & -1 & -1 & $\odot$ & - & $z$ & -7 & $z$ & -7 & - & -1 & in & ก & $\stackrel{7}{2}$ & $\infty$ \\
\hline tт0z & $z$ & $z$ & $z$ & $\sigma$ & $z$ & -1 & $z$ & $N$ & - & N & $z$ & $z$ & $z$ & $z$ & $z$ & $N$ & $\stackrel{7}{1}$ & $\stackrel{\mathscr{्}}{\circ}$ & กั \\
\hline ยтог & - & N & $\sim$ & $N$ & $z$ & $\sim$ & $z$ & $N$ & $z$ & $z$ & $z$ & - & $z$ & $z$ & $z$ & -1 & न & $\stackrel{\infty}{ఫ}$ & : \\
\hline ztor & $z$ & $z$ & - & - & $z$ & $\sim$ & $z$ & $N$ & $z$ & $z$ & $z$ & $z$ & $N$ & $z$ & -1 & $\sim$ & $m$ & 8 & ติ \\
\hline tт0z & $z$ & $z$ & $z$ & - & -4 & $\sim$ & -4 & 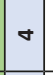 & $z$ & $z$ & -4 & $z$ & $z$ & n & $z$ & $\sim$ & I & $\stackrel{7}{\varrho}$ & $\bar{\Xi}$ \\
\hline otor & $z$ & $z$ & - & N & $z$ & + & $\rightarrow$ & $m$ & $z$ & $z$ & $z$ & $z$ & $z$ & $z$ & $z$ & $z$ & 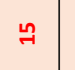 & $\mathscr{\infty}$ & $\hat{\text { in }}$ \\
\hline $600 z$ & - & $z$ & - & $z$ & $z$ & + & $z$ & -1 & $z$ & $z$ & $z$ & $z$ & $z$ & $z$ & $z$ & $z$ & 요 & $\exists$ & $ت$ \\
\hline 8002 & $z$ & $z$ & - & $z$ & $\rightarrow$ & $\sim$ & $\sim$ & $m$ & $z$ & $\rightarrow$ & $z$ & $z$ & $N$ & 4 & N & + & $\stackrel{\infty}{\sim}$ & $\stackrel{\circ}{\circ}$ & กั \\
\hline$\angle 00 z$ & $z$ & z & $z$ & $\sigma$ & $z$ & $\sim$ & $z$ & $\sim$ & $z$ & $z$ & $z$ & $N$ & $z$ & z & $z$ & -4 & ㅇ & $\stackrel{n}{\sim}$ & $\stackrel{m}{g}$ \\
\hline 9002 & N & - & $\sim$ & $z$ & -7 & - & $N$ & $m$ & -1 & $z$ & -4 & z & $z$ & $z$ & $z$ & $N$ & $\approx$ & $\vec{A}$ & ت্ \\
\hline sooz & z & $z$ & -1 & m & $z$ & $\sim$ & -1 & m & -1 & -1 & $z$ & $z$ & $z$ & - & $z$ & $m$ & $\approx$ & $\stackrel{\circ}{-}$ & హे \\
\hline tooz & z & $z$ & $z$ & N & - & $\sim$ & $z$ & m & $z$ & $z$ & -1 & -1 & -1 & $z$ & - & 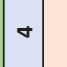 & $\approx$ & $\stackrel{\infty}{\infty}$ & $\vec{I}$ \\
\hline عooz & $z$ & - & - & $z$ & -1 & $z$ & $z$ & -7 & $z$ & $z$ & $z$ & -1 & $z$ & $z$ & $z$ & -1 & $F$ & $\stackrel{\circ}{7}$ & $\stackrel{n}{a}$ \\
\hline zo0z-I66ז & $z$ & $z$ & $z$ & $z$ & $z$ & $z$ & $z$ & $z$ & $z$ & $z$ & $z$ & $z$ & $z$ & $z$ & $z$ & $z \frac{c}{2}$ & 我 & 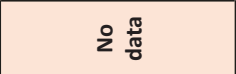 & \\
\hline $066 \tau$ & $z$ & $z$ & $z$ & $z$ & $z$ & $z$ & $z$ & $z$ & $z$ & $z$ & $z$ & $z$ & $z$ & $z$ & $z$ & $z$ & $m$ & ల్లి & $\begin{array}{l}\text { m. } \\
\text { m. } \\
\end{array}$ \\
\hline 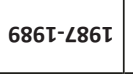 & $z$ & $z$ & $z$ & $z$ & $z$ & z & $z$ & $z$ & $z$ & $z$ & $z$ & z & $z$ & $z$ & $z$ & $z \frac{c}{2}$ & $20 \frac{\pi}{2}$ & 용 $\frac{\pi}{\frac{\pi}{0}}$ & \\
\hline $986 \tau$ & $z$ & $z$ & $N$ & $z$ & $z$ & $z$ & $z$ & $z$ & -1 & -1 & $z$ & $z$ & $z$ & $z$ & $z$ & $\sim$ & ㅇ & ¿ & : \\
\hline s8-६86โ & $z$ & $z$ & 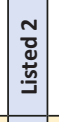 & z & $z$ & $z$ & $\circ$ & 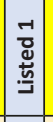 & $\circ$ & $z$ & z & $z$ & $z$ & $z$ & z & $\mid$ & 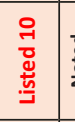 & 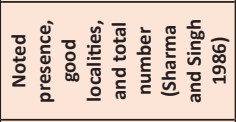 & \\
\hline 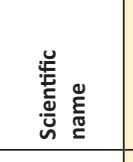 & 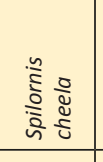 & 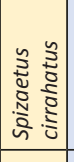 & & 离 & 告 & 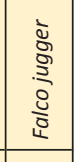 & 竞 & & 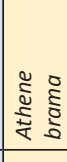 & 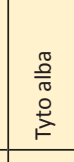 & 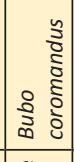 & 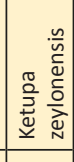 & 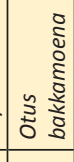 & 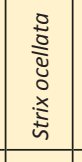 & 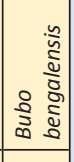 & \multirow{3}{*}{\multicolumn{2}{|c|}{ 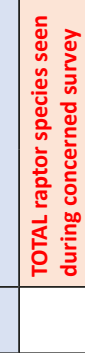 }} & \multirow{3}{*}{ 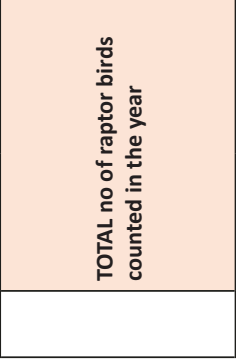 } & \multirow{3}{*}{ 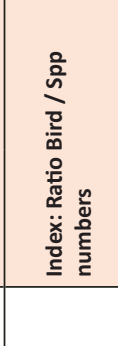 } \\
\hline 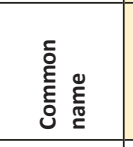 & 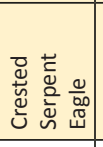 & 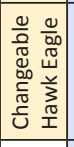 & & 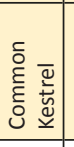 & 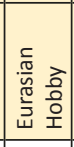 & 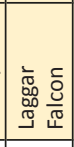 & 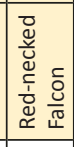 & & 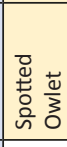 & 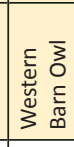 & 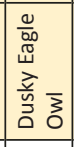 & 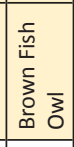 & 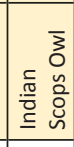 & 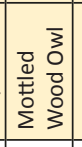 & 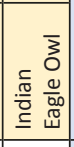 & & & & \\
\hline$\stackrel{\circ}{\circ}$ & $\stackrel{\infty}{\sim}$ & 9 & & ก & $\overline{4}$ & N & $\approx$ & & $g$ & เ & $\stackrel{i}{*}$ & 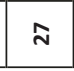 & $\stackrel{\infty}{\sim}$ & กิ & i & & & & \\
\hline
\end{tabular}


Supplement Table B. Raptors of National Chambal Sanctuary and their international and national status of protection with recommendation. CR-Critically Endangered | VU-Vulnerable | EN-Endangered | NT-Near Threatened | LC—Least Concern.

\begin{tabular}{|c|c|c|c|c|c|c|}
\hline $\begin{array}{l}\text { Species } \\
\text { Sl. No. }\end{array}$ & English name & Scientific name & $\begin{array}{l}\text { IUCN } \\
\text { Status }\end{array}$ & Status in Wildlife Act, 1972 & Cites Appendix & Migratory status \\
\hline 1 & Cinereous Vulture & Aegypius monachus & NT & $\begin{array}{l}\text { Schedule-IV } \\
\text { Cannot hunt without } \\
\text { permission }\end{array}$ & II & Winter visitor \\
\hline 2 & Egyptian Vulture & Neophron percnopterus & EN & Schedule-IV & ॥ & Resident \\
\hline 3 & $\begin{array}{l}\text { White-rumped Vulture } \\
\text { (Synonym: Indian White- } \\
\text { backed Vulture) }\end{array}$ & Gyps bengalensis & CR & Schedule-I & II & Resident \\
\hline 4 & $\begin{array}{l}\text { Indian Vulture } \\
\text { (Synonym: Long-billed } \\
\text { Vulture) }\end{array}$ & Gyps indicus & CR & Schedule-I & II & Resident \\
\hline 5 & Red-headed Vulture & Sarcogyps calvus & CR & Schedule-IV & II & Resident \\
\hline 6 & $\begin{array}{l}\text { Griffon Vulture } \\
\text { (Synonym: Eurasian Griffon) }\end{array}$ & Gyps fulvus & LC & Schedule-IV & II & Winter visitor \\
\hline 7 & $\begin{array}{l}\text { Western Osprey } \\
\text { (Synonym: Osprey) }\end{array}$ & Pandion haliaetus & LC & $\begin{array}{l}\text { Schedule-I } \\
\text { Fully protected }\end{array}$ & II & $\begin{array}{l}\text { Winter visitor, } \\
\text { seen till May }\end{array}$ \\
\hline 8 & Black-shouldered Kite & $\begin{array}{l}\text { Elanus axillaris } \\
\text { (Syn: E. caeruleus) }\end{array}$ & LC & Schedule-IV & II & Resident \\
\hline 9 & $\begin{array}{l}\text { Black Kite } \\
\text { (Syn: Common Pariah Kite) }\end{array}$ & Milvus migrans & LC & Schedule-IV & II & Resident \\
\hline 10 & Shikra & Accipiter badius & LC & Schedule-IV & II & Resident \\
\hline 11 & $\begin{array}{l}\text { Western Marsh Harrier } \\
\text { (Synonym: Eurasian Marsh } \\
\text { Harrier) }\end{array}$ & Circus aeruginosus & LC & Schedule-IV & II & Winter visitor \\
\hline 12 & Common Buzzard & Buteo buteo & LC & Schedule-IV & ॥ & Winter visitor \\
\hline 13 & White-eyed Buzzard & Butastur teesa & LC & Schedule-IV & II & Resident \\
\hline 14 & $\begin{array}{l}\text { Crested Honey Buzzard } \\
\text { (Synonym: Oriental Honey } \\
\text { Buzzard) }\end{array}$ & Pernis ptilorhynchus & LC & Schedule-IV & II & Resident \\
\hline 15 & Bonelli's Eagle & $\begin{array}{l}\text { Aquila fasciata } \\
\text { (Syn: Hieraaetus fasciatus) }\end{array}$ & LC & Schedule-IV & II & Resident \\
\hline 16 & Pallas's Fish Eagle & Haliaeetus leucoryphus & EN & No mention & II & Winter visitor \\
\hline 17 & Tawny Eagle & Aquila rapax & VU & Schedule-IV & II & Winter visitor \\
\hline 18 & Crested Serpent Eagle & Spilornis cheela & LC & Schedule-IV & II & Resident \\
\hline 19 & Changeable Hawk Eagle & $\begin{array}{l}\text { Nisaetus cirrhatus, Syn. } \\
\text { Spizaetus cirrhatus }\end{array}$ & LC & Schedule-IV & II & Resident \\
\hline 20 & Common Kestrel & Falco tinnunculus & LC & Schedule-IV & II & Winter visitor \\
\hline 21 & Eurasian Hobby & Falco subbuteo & LC & Schedule-IV & II & Winter visitor \\
\hline 22 & Laggar Falcon & Falco jugger & NT & Schedule-I & I (One) & Resident \\
\hline 23 & Red-necked Falcon & Falco chicquera & NT & Schedule-I & II & Resident \\
\hline 24 & Spotted Owlet & Athene brama & LC & Schedule-IV & II & Resident \\
\hline 25 & $\begin{array}{l}\text { Western Barn Owl } \\
\text { (Synonym: Barn Owl) }\end{array}$ & Tyto alba & LC & Schedule-IV & II & Resident \\
\hline 26 & Dusky Eagle Owl & Bubo coromandus & LC & Schedule-IV & II & Resident \\
\hline 27 & Brown Fish Owl & $\begin{array}{l}\text { Ketupa zeylonensis } \\
\text { (Synonym: } \\
\text { Bubo zeylonensis) }\end{array}$ & LC & Schedule-IV & II & Resident \\
\hline 28 & Indian Scops Owl & Otus bakkamoena & LC & Schedule-IV & II & Resident \\
\hline 29 & Mottled Wood Owl & Strix ocellata & LC & Schedule-IV & II & Resident \\
\hline 30 & $\begin{array}{l}\text { Indian Eagle-Owl } \\
\text { (Synonym: Rock Eagle Owl) }\end{array}$ & Bubo bengalensis & LC & Schedule-IV & II & Resident \\
\hline
\end{tabular}



Dr. John Noyes, Natural History Museum, London, UK

Dr. Albert G. Orr, Griffith University, Nathan, Australia

Dr. Sameer Padhye, Katholieke Universiteit Leuven, Belgium

Dr. Nancy van der Poorten, Toronto, Canada

Dr. Kareen Schnabel, NIWA, Wellington, New Zealand

Dr. R.M. Sharma, (Retd.) Scientist, Zoological Survey of India, Pune, India

Dr. Manju Siliwal, WILD, Coimbatore, Tamil Nadu, India

Dr. G.P. Sinha, Botanical Survey of India, Allahabad, India

Dr. K.A. Subramanian, Zoological Survey of India, New Alipore, Kolkata, India

Dr. P.M. Sureshan, Zoological Survey of India, Kozhikode, Kerala, India

Dr. R. Varatharajan, Manipur University, Imphal, Manipur, India

Dr. Eduard Vives, Museu de Ciències Naturals de Barcelona, Terrassa, Spain

Dr. James Young, Hong Kong Lepidopterists' Society, Hong Kong

Dr. R. Sundararaj, Institute of Wood Science \& Technology, Bengaluru, India

Dr. M. Nithyanandan, Environmental Department, La Ala Al Kuwait Real Estate. Co. K.S.C.,

Kuwait

Dr. Himender Bharti, Punjabi University, Punjab, India

Mr. Purnendu Roy, London, UK

Dr. Saito Motoki, The Butterfly Society of Japan, Tokyo, Japan

Dr. Sanjay Sondhi, TITLI TRUST, Kalpavriksh, Dehradun, India

Dr. Nguyen Thi Phuong Lien, Vietnam Academy of Science and Technology, Hanoi, Vietnam

Dr. Nitin Kulkarni, Tropical Research Institute, Jabalpur, India

Dr. Robin Wen Jiang Ngiam, National Parks Board, Singapore

Dr. Lional Monod, Natural History Museum of Geneva, Genève, Switzerland.

Dr. Asheesh Shivam, Nehru Gram Bharti University, Allahabad, India

Dr. Rosana Moreira da Rocha, Universidade Federal do Paraná, Curitiba, Brasi

Dr. Kurt R. Arnold, North Dakota State University, Saxony, Germany

Dr. James M. Carpenter, American Museum of Natural History, New York, USA

Dr. David M. Claborn, Missouri State University, Springfield, USA

Dr. Kareen Schnabel, Marine Biologist, Wellington, New Zealand

Dr. Amazonas Chagas Júnior, Universidade Federal de Mato Grosso, Cuiabá, Brasil

Mr. Monsoon Jyoti Gogoi, Assam University, Silchar, Assam, India

Dr. Heo Chong Chin, Universiti Teknologi MARA (UiTM), Selangor, Malaysia

Dr. R.J. Shiel, University of Adelaide, SA 5005, Australia

Dr. Siddharth Kulkarni, The George Washington University, Washington, USA

Dr. Priyadarsanan Dharma Rajan, ATREE, Bengaluru, India

Dr. Phil Alderslade, CSIRO Marine And Atmospheric Research, Hobart, Australia

Dr. John E.N. Veron, Coral Reef Research, Townsville, Australia

Dr. Daniel Whitmore, State Museum of Natural History Stuttgart, Rosenstein, Germany.

Dr. Yu-Feng Hsu, National Taiwan Normal University, Taipei City, Taiwan

Dr. Keith V. Wolfe, Antioch, California, USA

Dr. Siddharth Kulkarni, The Hormiga Lab, The George Washington University, Washington,

D.C., USA

Dr. Tomas Ditrich, Faculty of Education, University of South Bohemia in Ceske

Budejovice, Czech Republic

Dr. Mihaly Foldvari, Natural History Museum, University of Oslo, Norway

Dr. V.P. Uniyal, Wildlife Institute of India, Dehradun, Uttarakhand 248001, India

Dr. John T.D. Caleb, Zoological Survey of India, Kolkata, West Bengal, India

Dr. Priyadarsanan Dharma Rajan, Ashoka Trust for Research in Ecology and the Environment

(ATREE), Royal Enclave, Bangalore, Karnataka, India

\section{Fishes}

Dr. Neelesh Dahanukar, IISER, Pune, Maharashtra, India

Dr. Topiltzin Contreras MacBeath, Universidad Autónoma del estado de Morelos, México

Dr. Heok Hee Ng, National University of Singapore, Science Drive, Singapore

Dr. Rajeev Raghavan, St. Albert's College, Kochi, Kerala, India

Dr. Robert D. Sluka, Chiltern Gateway Project, A Rocha UK, Southall, Middlesex, UK

Dr. E. Vivekanandan, Central Marine Fisheries Research Institute, Chennai, India

Dr. Davor Zanella, University of Zagreb, Zagreb, Croatia

Dr. A. Biju Kumar, University of Kerala, Thiruvananthapuram, Kerala, India

Dr. Akhilesh K.V., ICAR-Central Marine Fisheries Research Institute, Mumbai Research

Centre, Mumbai, Maharashtra, India

Dr. J.A. Johnson, Wildlife Institute of India, Dehradun, Uttarakhand, India

Amphibians

Dr. Sushil K. Dutta, Indian Institute of Science, Bengaluru, Karnataka, India

Dr. Annemarie Ohler, Muséum national d'Histoire naturelle, Paris, France

\section{Reptiles}

Dr. Gernot Vogel, Heidelberg, Germany

Dr. Raju Vyas, Vadodara, Gujarat, India

Dr. Pritpal S. Soorae, Environment Agency, Abu Dubai, UAE.

Prof. Dr. Wayne J. Fuller, Near East University, Mersin, Turkey

Prof. Chandrashekher U. Rivonker, Goa University, Taleigao Plateau, Goa. India

Dr. S.R. Ganesh, Chennai Snake Park, Chennai, Tamil Nadu, India

Dr. Himansu Sekhar Das, Terrestrial \& Marine Biodiversity, Abu Dhabi, UAE
Birds

Dr. Hem Sagar Baral, Charles Sturt University, NSW Australia

Dr. Chris Bowden, Royal Society for the Protection of Birds, Sandy, UK

Dr. Priya Davidar, Pondicherry University, Kalapet, Puducherry, India

Dr. J.W. Duckworth, IUCN SSC, Bath, UK

Dr. Rajah Jayapal, SACON, Coimbatore, Tamil Nadu, India

Dr. Rajiv S. Kalsi, M.L.N. College, Yamuna Nagar, Haryana, India

Dr. V. Santharam, Rishi Valley Education Centre, Chittoor Dt., Andhra Pradesh, India

Dr. S. Balachandran, Bombay Natural History Society, Mumbai, India

Mr. J. Praveen, Bengaluru, India

Dr. C. Srinivasulu, Osmania University, Hyderabad, India

Dr. K.S. Gopi Sundar, International Crane Foundation, Baraboo, USA

Dr. Gombobaatar Sundev, Professor of Ornithology, Ulaanbaatar, Mongolia

Prof. Reuven Yosef, International Birding \& Research Centre, Eilat, Israel

Dr. Taej Mundkur, Wetlands International, Wageningen, The Netherlands

Dr. Carol Inskipp, Bishop Auckland Co., Durham, UK

Dr. Tim Inskipp, Bishop Auckland Co, Durham, UK

Dr. V. Gokula, National College, Tiruchirappalli, Tamil Nadu, India

Dr. Arkady Lelej, Russian Academy of Sciences, Vladivostok, Russia

Dr. Simon Dowell, Science Director, Chester Zoo, UK

Dr. Mário Gabriel Santiago dos Santos, Universidade de Trás-os-Montes e Alto Douro,

Quinta de Prados, Vila Real, Portugal

Dr. Grant Connette, Smithsonian Institution, Royal, VA, USA

Dr. M. Zafar-ul Islam, Prince Saud Al Faisal Wildlife Research Center, Taif, Saudi Arabia

Mammals

Dr. Giovanni Amori, CNR - Institute of Ecosystem Studies, Rome, Italy

Dr. Anwaruddin Chowdhury, Guwahati, India

Dr. David Mallon, Zoological Society of London, UK

Dr. Shomita Mukherjee, SACON, Coimbatore, Tamil Nadu, India

Dr. Angie Appel, Wild Cat Network, Germany

Dr. P.O. Nameer, Kerala Agricultural University, Thrissur, Kerala, India

Dr. Ian Redmond, UNEP Convention on Migratory Species, Lansdown, UK

Dr. Heidi S. Riddle, Riddle's Elephant and Wildlife Sanctuary, Arkansas, USA

Dr. Karin Schwartz, George Mason University, Fairfax, Virginia.

Dr. Lala A.K. Singh, Bhubaneswar, Orissa, India

Dr. Mewa Singh, Mysore University, Mysore, India

Dr. Paul Racey, University of Exeter, Devon, UK

Dr. Honnavalli N. Kumara, SACON, Anaikatty P.O., Coimbatore, Tamil Nadu, India

Dr. Nishith Dharaiya, HNG University, Patan, Gujarat, India

Dr. Spartaco Gippoliti, Socio Onorario Società Italiana per la Storia della Fauna "Giuseppe

Altobello", Rome, Italy

Dr. Justus Joshua, Green Future Foundation, Tiruchirapalli, Tamil Nadu, India

Dr. H. Raghuram, The American College, Madurai, Tamil Nadu, India

Dr. Paul Bates, Harison Institute, Kent, UK

Dr. Jim Sanderson, Small Wild Cat Conservation Foundation, Hartford, USA

Dr. Dan Challender, University of Kent, Canterbury, UK

Dr. David Mallon, Manchester Metropolitan University, Derbyshire, UK

Dr. Brian L. Cypher, California State University-Stanislaus, Bakersfield, CA

Dr. S.S. Talmale, Zoological Survey of India, Pune, Maharashtra, India

Prof. Karan Bahadur Shah, Budhanilakantha Municipality, Kathmandu, Nepal

Dr. Susan Cheyne, Borneo Nature Foundation International, Palangkaraja, Indonesia

Dr. Hemanta Kafley, Wildlife Sciences, Tarleton State University, Texas, USA

\section{Other Disciplines}

Dr. Aniruddha Belsare, Columbia MO 65203, USA (Veterinary)

Dr. Mandar S. Paingankar, University of Pune, Pune, Maharashtra, India (Molecular)

Dr. Jack Tordoff, Critical Ecosystem Partnership Fund, Arlington, USA (Communities)

Dr. Ulrike Streicher, University of Oregon, Eugene, USA (Veterinary)

Dr. Hari Balasubramanian, EcoAdvisors, Nova Scotia, Canada (Communities)

Dr. Rayanna Hellem Santos Bezerra, Universidade Federal de Sergipe, São Cristóvão, Brazil

Dr. Jamie R. Wood, Landcare Research, Canterbury, New Zealand

Dr. Wendy Collinson-Jonker, Endangered Wildlife Trust, Gauteng, South Africa

Dr. Rajeshkumar G. Jani, Anand Agricultural University, Anand, Gujarat, India

Dr. O.N. Tiwari, Senior Scientist, ICAR-Indian Agricultural Research Institute (IARI), New

Delhi, India

Dr. L.D. Singla, Guru Angad Dev Veterinary and Animal Sciences University, Ludhiana, India

Dr. Rupika S. Rajakaruna, University of Peradeniya, Peradeniya, Sri Lanka

Dr. Bahar Baviskar, Wild-CER, Nagpur, Maharashtra 440013, India

Reviewers 2018-2020

Due to pausity of space, the list of reviewers for $2018-2020$ is available online.

The opinions expressed by the authors do not reflect the views of the Journal of Threatened Taxa, Wildlife Information Liaison Development Society, Zoo Outreach Organization, or any of the partners. The journal, the publisher, the host, and the partners are not responsible for the accuracy of the political boundaries shown in the maps by the authors.

Journal of Threatened Taxa is indexed/abstracted in Bibliography of Systematic Mycology, Biological Abstracts, BIOSIS Previews, CAB Abstracts, EBSCO, Google Scholar, Index Copernicus, Index Fungorum, JournalSeek, National Academy of Agricultural Sciences, NewJour, OCLC WorldCat, SCOPUS, Stanford University Libraries, Virtual Library of Biology, Zoological Records.

NAAS rating (India) 5.64
Print copies of the Journal are available at cost. Write to:

The Managing Editor, JoTT,

c/o Wildlife Information Liaison Development Society,

No. 12, Thiruvannamalai Nagar, Saravanampatti - Kalapatti Road,

Saravanampatti, Coimbatore, Tamil Nadu 641035, India

ravi@threatenedtaxa.org 


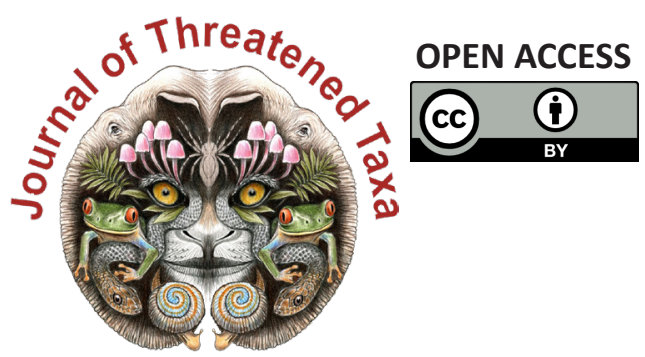

www.threatenedtaxa.org

The Journal of Threatened Taxa (JoTT) is dedicated to building evidence for conservation globally by publishing peer-reviewed articles online every month at a reasonably rapid rate at www.threatenedtaxa.org. All articles published in JoTT are registered under Creative Commons Attribution 4.0 International License unless otherwise mentioned. JoTT allows allows unrestricted use, reproduction, and distribution of articles in any medium by providing adequate credit to the author(s) and the source of publication.

\section{ISSN $0974-7907$ (Online) | ISSN $0974-7893$ (Print)}

\section{January 2022 | Vol. 14 | No. 1 | Pages: 20311-20538 \\ Date of Publication: 26 January 2022 (Online \& Print) DOI: 10.11609/jott.2022.14.1.20311-20538}

Articles

Estimating the completeness of orchid checklists and atlases: a case study from southern Italy

- Antonio Croce, Pp. 20311-20322

A floristic survey across three coniferous forests of Kashmir Himalaya, India - a checklist

- Ashaq Ahmad Dar, Akhtar Hussain Malik \& Narayanaswamy Parthasarathy, Pp. 20323-20345

Associations of butterflies across different forest types in Uttarakhand, western Himalaya, India: implications for conservation planning

- Arun Pratap Singh, Pp. 20346-20370

Comparison of bird diversity in protected and non-protected wetlands of western lowland of Nepal

- Jagan Nath Adhikari, Janak Raj Khatiwada, Dipendra Adhikari, Suman Sapkota, Bishnu Prasad Bhattarai, Deepak Rijal \& Lila Nath Sharma, Pp. 20371-20386

Local hunting practices and perceptions regarding the distribution and ecological role of the Large Flying Fox (Chiroptera: Pteropodidae: Pteropus vampyrus) in western Sarawak, Malaysian Borneo

- Jayasilan Mohd-Azlan, Joon Yee Yong, Nabila Norshuhadah Mohd Hazzrol, Philovenny Pengiran, Arianti Atong \& Sheema Abdul Aziz, Pp. 20387-20399

\section{Communications}

Macrolichens of Mathikettan Shola National Park, Western Ghats: a preliminary investigation with some new records

- Aswathi Anilkumar, Stephen Sequeira, Arun Christy \& S.M. Arsha, Pp. 20400-20405

New distribution record of globally threatened Ocean Turf Grass Halophila beccarii Ascherson, 1871 from the North Andaman Islands highlights the importance of seagrass exploratory surveys

- Swapnali Gole, Prasad Gaidhani, Srabani Bose, Anant Pande, Jeyaraj Antony Johnson \& Kuppusamy Sivakumar, Pp. 20406-20412

An inventory of new orchid (Orchidaceae) records from Kozhikode, Kerala, India - M. Sulaiman, C. Murugan \& M.U. Sharief, Pp. 20413-20425

Abundance and spatial distribution analyses of Stemonoporus moonii Thwaites (Dipterocarpaceae) - a critically endangered species endemic to Sri Lanka - K.A.M.R.P. Atapattu, H.D.D.C.K. Perera, H.S. Kathriarachchi \& A.R. Gunawardena, Pp. 20426-20432

Plant diversity of Point Calimere Wildlife Sanctuary and fodder species grazed by the Blackbuck Antilope cervicapra L.

- Ashutosh Kumar Upadhyay, A. Andrew Emmanuel, Ansa Sarah Varghese \&

D. Narasimhan, Pp. 20433-20443

Raptors observed (1983-2016) in National Chambal Gharial Sanctuary: semi-arid biogeographic region suggestions for parametric studies on ecological continuity in Khathiar-Gir Ecoregion, India

- L.A.K. Singh, R.K. Sharma \& Udayan Rao Pawar, Pp. 20444-20460

Nesting success of Sharpe's Longclaw (Macronyx sharpei Jackson, 1904) around the grasslands of lake Ol'bolossat Nyandarua, Kenya

- Hamisi Ann Risper, Charles M. Warui \& Peter Njoroge, Pp. 20461-20468

Population, distribution and diet composition of Smooth-coated Otter Lutrogale perspicillata Geoffroy, 1826 in Hosur and Dharmapuri Forest Divisions, India - Nagarajan Baskaran, Raman Sivaraj Sundarraj \& Raveendranathanpillai Sanil, Pp. 20469-20477

Utilization of home garden crops by primates and current status of human-primate interface at Galigamuwa Divisional Secretariat Division in Kegalle District, Sri Lanka

- Charmalie Anuradhie Dona Nahallage, Dahanakge Ayesha Madushani Dasanayake, Dilan Thisaru Hewamanna \& Dissanayakalage Tharaka Harshani Ananda, Pp. 2047820487
Revival of Eastern Swamp Deer Rucervus duvaucelii ranjitsinhi (Groves, 1982) in Manas National Park of Assam, India

- Nazrul Islam, Aftab Ahmed, Rathin Barman, Sanatan Deka, Bhaskar Choudhury, Prasanta Kumar Saikia \& Jyotishman Deka, Pp. 20488-20493

Trypanosoma evansi infection in a captive Indian Wolf Canis lupus pallipes - molecular diagnosis and therapy

- Manojita Dash, Sarat Kumar Sahu, Santosh Kumar Gupta, Niranjana Sahoo \& Debarat Mohapatra, Pp. 20494-20499

View Point

COVID-19 and civil unrest undoing steady gains in karst conservation and herpetological research in Myanmar, and an impediment to progress - Evan S.H. Quah, Lee L. Grismer, Perry L. Wood, Jr., Aung Lin \& Myint Kyaw Thura, Pp. 20500-20502

\section{Short Communications}

Morphological characterization and mt DNA barcode of a tiger moth species, Asota ficus (Fabricius, 1775) (Lepidoptera: Noctuoidea: Erebidae: Aganainae) from India - Aparna Sureshchandra Kalawate, K.P. Dinesh \& A. Shabnam, Pp. 20503-20510

Distribution of Smooth-coated Otters Lutrogale perspicillata (Mammalia: Carnivora: Mustelidae): in Ratnagiri, Maharashtra, India

- Swanand Patil \& Kranti Yardi, Pp. 20511-20516

Wildlife at the crossroads: wild animal road kills due to vehicular collision on a mountainous highway in northwestern Himalayan region

- Muzaffar A. Kichloo, Asha Sohil \& Neeraj Sharma, Pp. 20517-20522

Notes

Robiquetia gracilis (Lindl.) Garay-a new record to the flora of Anamalai Hills, Tami Nadu, India

- B. Subbaiyan, V. Ganesan, P.R. Nimal Kumar \& S. Thangaraj Panneerselvam, Pp. 20523-20525

Ipomoea laxiflora H.J. Chowdhery \& Debta (Convolvulaceae): new records for the Western Ghats and semiarid regions

- Sachin M. Patil, Ajit M. Vasava, Vinay M. Raole \& Kishore S. Rajput, Pp. 20526-20529

Counting the cost: high demand puts Bunium persicum (Boiss.) B.Fedtsch. in jeopardy

- Monika Sharma, Manisha Mathela, Rupali Sharma, Himanshu Bargali, Gurinderjit S Goraya \& Amit Kumar, Pp. 20530-20533

First record of Parasitic Jaeger Stercorarius parasiticus (Aves: Charadriiformes: Stercorariidae) from inland freshwater Inle Lake, Myanmar

- Sai Sein Lin Oo, Myint Kyaw, L.C.K. Yun, Min Zaw Tun, Yar Zar Lay Naung, Soe Naing Aye \& Swen C. Renner, Pp. 20534-20536

\section{Book Review}

Capparis of India

- V. Sampath Kumar, Pp. 20537-20538
Publisher \& Host
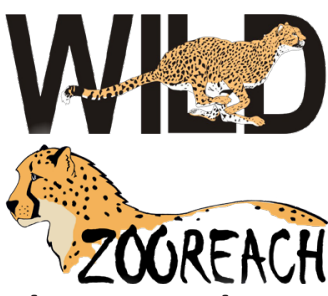

Threatened Taxa 